\title{
Las actitudes políticas de Manuel de Falla: confianza, desconcierto y prevención
}

\author{
Manuel Titos MartíneZ \\ Universidad de Granada \\ mtitos@ugr.es
}

Recibido: $16 / 05 / 2011$

Aceptado: 07/07/2011

\section{RESUMEN}

Manuel de Falla abandonó España al terminar la Guerra Civil y se instaló en Argentina hasta el fin de sus días, lo que ha inducido a algunos autores a considerar este viaje como su exilio político. Pero nada más lejos de la personalidad del compositor que manifestar su descontento de manera tan rotunda. Con documentación de su archivo personal, este trabajo analiza el entorno político en el que Falla se desenvolvió, la forma en que la política colisionó con sus profundas convicciones religiosas y con el trágico destino de sus más queridos amigos, en qué medida su viaje a Argentina estuvo motivado más por la precaria economía del compositor que por la situación política del país, así como las diferentes formas mediante las que el Franquismo le trató de utilizar y las sutiles y aparentemente contradictorias maneras que éste utilizó para su resistencia.

Palabras clave: Manuel de Falla, Leopoldo Matos, exilio español en Argentina, músicos españoles.

The Political Attitudes in the Life of Manuel de Falla: Trust, Bewilderment and Caution

\begin{abstract}
This paper revises the idea that Manuel de Falla decided to leave Spain at the end of the Civil War and settled down in Argentina as a sort of political exile. Drawing upon documentary sources from his personal archives, these pages intend to show how Falla's character was far from showing disappointment in such a blatant fashion. Thus, some key issues are examined, such as the political milieu he frequented, how the dramatic political events confronted his strong religious beliefs or the impact of the tragedies experienced by his closest friends. In addition, it is possible to gauge to what extent his trip to Argentina was caused by economic precariousness rather than political problems, as well as the different means by which Franco's regime tried to take advantage of his prestige and the subtle and apparently paradoxical resorts Falla plotted to counteract it.
\end{abstract}

Key words: Manuel de Falla, Leopoldo Matos, Spanish exile in Argentina, Spanish musicians.

Sumario: Introducción. 1. El costo de no tener padrinos. 2. Ayuda para un músico. 3. La República no es quemar iglesias. 4. Recluido en una Granada en guerra. 5. La tentación de la Patria.

\section{Introducción}

Manuel de Falla abandonó España a bordo del buque "Neptunia" el 18 de octubre de 1939, seis meses después de terminada la Guerra Civil. Sus restos mortales llegaron a Cádiz a bordo de "El Cañonero", un buque de la armada española, el 9 de enero de 1947. Había fallecido en Alta Gracia (Córdoba) el 14 de noviembre anterior, cuando le faltaban nueve días para cumplir los setenta años. Durante los siete que permane- 
ció en Argentina, siempre afirmó su deseo de regresar a su país. Nunca lo hizo, con vida. Ello ha dado pie para que algunos de quienes se han acercado a la vida de Manuel de Falla hayan hablado del exilio político del más célebre de los compositores españoles del siglo XX, incompatible para convivir con un régimen que ya se presuponía largo y duro ${ }^{1}$. Pero esto, sin dejar de ser cierto de manera absoluta, tampoco resulta veraz en su totalidad. Falla es el prototipo del comedimiento, del equilibrio, de la mesura... al menos en su comportamiento personal. Otra cosa sería el artístico, mucho más rompedor, en opinión de los musicólogos. Y ese comportamiento está tan lleno de matices, de contradicciones aparentes, de silencios inducidos por la depresión ante su propio desconcierto, del enfrentamiento de sus propios sentimientos, de la tragedia, en fin, ante la elección de lealtades personales. Así pues, resulta fácil pronunciarse por las apariencias y aplicando nuestra lógica, pero no lo es tanto hacerlo con acierto, de manera que nuestro juicio se corresponda con lo que el compositor vivió y sintió en aquellos terribles momentos, principalmente a partir de las primeras agitaciones que tienen lugar en el mes de mayo de 1931 y, sobre todo, del verano de 1936.

Lo que en muchas ocasiones le dictaba su conciencia, no estaba en armonía con lo que imponían los acontecimientos y si había que plegarse a éstos, el diferente posicionamiento de sus amigos y el fatal destino de algunos de los más queridos, en uno y otro bando, le consumía en el desconcierto, en el dolor y en la depresión más profundos. Entre el corazón y la razón no siempre hubo armonía y de aquella tensión nació una tragedia personal que paralizó su acción. Hasta que la razón se fue imponiendo, muy lenta, mesurada y educadamente, como siempre en la vida del compositor, pero con una firmeza en su voluntad que bien demostró en varias ocasiones a lo largo de su vida.

En cualquier caso, valga como anticipo la afirmación, obvia por otra parte, de que Manuel de Falla no fue un hombre implicado en la política. Ni temperamental ni ocasionalmente. Y cuando lo hizo, fue siempre preocupado por elegir el camino más conveniente para los demás, menos dañino para los que le rodeaban y con un propósito de obtener ayuda para el prójimo, que le acompañó durante toda su existencia. Para su familia, para sus amigos y para sus colegas, sucumbiendo a la tentación apenas lo suficiente para que aquella línea de socorro funcionara, pero sin que de la misma pudiera deducirse una inequívoca e incondicional actitud de apoyo hacia unos comportamientos políticos que siempre le produjeron más miedo que esperanza. Ni el imperialismo alemán, ni el ultranacionalismo español, ni, posiblemente, el régimen dictatorial y populista argentino, aunque respecto de este último sus opiniones, que sepamos, se las guardó como huésped respetuoso y agradecido.

${ }^{1}$ TRAPIELLO, Andrés: Las armas y las letras. Literatura y Guerra Civil (1936-1939), Barcelona, Ediciones Destino, 2010 ( $2^{\mathrm{a}}$ edición), p. 267. Se excede el autor cuando afirma que "el ferviente católico Falla, al término de la guerra, se exilió en Argentina y no volvió nunca a pisar suelo español, poniendo tierra y mar de por medio con aquellos asesinos que debía de considerar escasamente cristianos". 


\section{El costo de no tener padrinos}

No fue la familia de Manuel de Falla gente que se hubiera dejado seducir por la política en el Cádiz de la Restauración. Familia acomodada y bien situada en los negocios, no tenemos constancia de que su padre, José María de Falla hubiera tenido, antes de devenir en la ruina más absoluta, alguna simpatía por los conservadores o por los liberales. En cualquier caso daría igual, porque las diferencias entre aquellos dos partidos derivaban más de la oportunidad que de la ideología. Otra cosa distinta ocurriría si hubiera llegado a tener algún contacto con los movimientos sindicales o republicanos, pero no fue el caso de don José María que, bien relacionado con la iglesia y con la burguesía porteña, se mantuvo, seguramente, leal al "orden" de la Restauración 2 .

Producida la ruina total de la familia Falla-Matheu, perdidas sus propiedades en Cádiz y trasladados a Madrid a mediados de 1899, el padre consiguió un empleo de "aspirante a oficial de segunda clase" en la Dirección General del Tesoro PúblicoOrdenación de Pagos del Estado", del que tomó posesión el día 26 de julio ${ }^{3}$. Había entonces en España un Gobierno conservador, el de Francisco Silvela y aunque los puestos funcionariales se movían al vaivén de las influencias que se tuvieran en el Gobierno de turno, no parece que un cargo tan poco relevante tuviera su origen en la "amistad política". En cualquier caso, aquello duró poco y desde luego no evitó que la familia tuviera que empezar a vender su ajuar para poder sobrevivir en el Madrid de comienzos del siglo XX, donde únicamente contaba con el apoyo de Emilia Matheu, hermana de la madre de Manuel, casada con Manuel Ledesma, un abogado ejerciente en Madrid, que ayudó a financiar los estudios de arquitectura del hermano menor, Germán.

Sobrevivió en Madrid don José María de Falla Franco con trabajos de mala muerte en algunas gestorías y como agente de seguros y únicamente volvió a rozar el empleo público en plena guerra mundial, en 1916, en cuya consecución, ahora, no es descartable que tuviera algo que ver alguien que ya era uno de los más estrechos amigos de Manuel de Falla, Leopoldo Matos, muy bien situado, como se verá, en el cacicato canario y en la política nacional. Así, Falla Franco fue nombrado el 1 de enero de 1916 auxiliar temporero en la Dirección General de Obras Públicas con un haber diario de tres pesetas. El 31 de enero fue declarado cesante, pero es porque tres días antes había sido nombrado escribiente de la Sección Especial de Estadística en la Dirección General de Comercio, Industria y Trabajo, con una remuneración mensual de 125 pesetas. El 30 de diciembre de aquel mismo año fue declarado cesante en tal empleo, sin que conste otra ocupación posterior. Pero aquel año en que el padre de Falla trabajó para el Ministerio de Fomento, el Gobierno estaba presidido por un liberal, el conde de Romanones, y el amigo Matos era conservador, de manera que no parece que estos efímeros empleos tuvieran algo que ver con la afinidad política

${ }^{2}$ Una ampliación de los aspectos económicos en la vida de Manuel de Falla puede verse en TITOS MARTÍNEZ, Manuel: Música y Finanzas. Biografía económica de Manuel de Falla, Granada, Archivo Manuel de Falla y Centro de Documentación Musical de la Junta de Andalucía, 2008.

${ }^{3}$ Archivo Manuel de Falla en Granada (AMF en lo sucesivo), carpeta 8.929. Cuestiones legales. Familia Falla-Matheu. 
de José María de Falla. Al contrario, tal vez la falta de ésta le impidió una mejor situación laboral.

Unos años antes comenzó a cruzarse una de las más abundantes correspondencias de Manuel de Falla, la que realizó con Leopoldo Matos quien, con el tiempo, se convertiría en su amigo más constante, sincero y leal, el receptor de sus confidencias, su sostén económico cuando el maestro lo necesitó, su "cajero" personal y su asesor financiero, cuando Falla dispuso de recursos excedentarios en su siempre discreta economía familiar. La primera carta conservada entre ellos es una que Falla le remitió el 23 de septiembre de 1909 desde París, donde Falla residía desde 1907, en la que, en respuesta a una anterior de Matos, le informaba sobre su salud, viajes, conciertos y proyectos y le invita a ir a París ${ }^{4}$. Matos aceptó aquella invitación y el 17 de mayo de 1910 le informaba que "Dentro de unos días iré a París y como es natural necesito que tú me recibas y guíes mis pasos" ". Lo más inquietante de aquella correspondencia, a los efectos que ahora nos interesan, es la pregunta que Falla le hace en su carta del 2 de noviembre de 1910, a un hombre ya vinculado a la política del conservadurismo como era Matos, que acababa de ser elegido diputado al Congreso por Las Palmas en mayo de aquel año y que se mantuvo hasta su muerte fiel a los principios de la monarquía alfonsina: “¿Para cuándo se proclama la República en España?”. ¿Qué información manejaban Matos y Falla como para dar como posible un acontecimiento semejante en la España de aquellos momentos? Lamentablemente, la pregunta no tiene respuesta para nosotros, porque el "nubarrón" de la Semana Trágica del año anterior no daba realmente para un cambio de régimen y la crisis que haría languidecer al sistema estaba aún a dos años del comienzo de su largo y tortuoso recorrido.

\section{Ayuda para un músico}

En cualquier caso, de la propia formulación de la pregunta no se deduce ninguna intencionalidad política y tal vez se trate de una simple broma a su amigo monárquico, porque Falla, nunca olvidó la ayuda que el propio rey de España le había brindado en 1908 cuando gracias a la mediación de Albéniz consiguió una subvención de la Corona española por valor de mil francos ${ }^{7}$. Albéniz debió hablar con la marquesa de Nájera, ésta con la infanta Isabel, que a su vez lo hizo con su sobrino, el rey Alfonso, quien, a través del marqués de Borja comunicó a Falla el donativo y le hizo llegar su importe. Que, por cierto, no fue una beca anual, como se ha dicho a veces, sino una ayuda ocasional que no tuvo continuidad ${ }^{8}$. Falla sabía perfectamente el origen

\footnotetext{
${ }^{4}$ Archivo Histórico de Las Palmas de Gran Canaria (AHLP en lo sucesivo). Fotocopia en AMF, carpeta 7.265/2.

${ }^{5}$ AMF, carpeta 7.265/1.

${ }^{6}$ AHLP. Fotocopia en AMF, carpeta 7.265/2.

${ }^{7}$ A un cambio de 113,02 pesetas los cien francos, mil francos se valdrían 1.130 pesetas corrientes, equivalentes a 4.275,21 euros constantes a enero de 2011.

${ }^{8}$ BONASTRE, Francesc: "Un dietario inédito de Manuel de Falla (Paris, 1908)", en FALLA, Manuel de: Apuntes de Harmonía. Dietario de París (1908), Granada, Publicaciones del Archivo Manuel de Falla, 2001, p. 284.
} 
de la gestión y así se lo dijo al propio Albéniz: "Ha conseguido Vd. querido Maestro, lo que nadie había podido conseguir, pues aunque no sea la pensión regular, ya con estos mil francos y lo que me dejen los conciertos podré trabajar tranquilo por unos meses". Meses que le permitieron terminar las Cuatro piezas españolas en las que había comenzado a trabajar en 1906.

Pero que Falla no tenía entonces ninguna relación con alguien bien situado en el Gobierno se puede deducir del hecho de que por dos veces solicitó una ayuda de la Junta para la Ampliación de Estudios, creada en 1907 para ayudar a los licenciados universitarios a completar su formación en el extranjero y en ambas ocasiones le fue denegada. De la primera sabemos, por una carta de Matos fechada el 6 de mayo de 1911, que él había hablado con el compositor Gustavo Pittaluga y éste con Ramón y Cajal, presidente de la Junta, quien le informó que el dictamen para la concesión de las ayudas había sido elaborado por el crítico y musicólogo Cecilio Roda y que éste no había considerado pertinente incluir a Falla entre los beneficiarios de las mismas. Matos le recomendó utilizar aquel procedimiento tan frecuente en la España de la Restauración, y aún después, el de la recomendación:

"Lo más conveniente es obtener el apoyo de Roda; yo no lo conozco, pero como es íntimo de Miguel Salvador te aconsejo que en seguida le escribas a éste, recordándole tus pretensiones, aunque sin hacer referencia a cuanto sobre el particular te he dicho yo en mis cartas. No dejes de escribirle al hijo de Don Amós ${ }^{10}$, tan pronto recibas ésta, pues lo que él no consiga de Roda difícilmente lo conseguirá otro"11.

Aquella gestión resultó fallida y Manuel de Falla en una carta que dirigió a Matos desde París el 29 de agosto de ese mismo año le informaba que había vuelto a formular la solicitud en una nueva convocatoria y que estaba esperando los resultados "que seguramente serán negativos" 12 , lo que es probable que volviera a ocurrir. $\mathrm{Ni}$ Falla era entonces conocido en España como para que su nombre fuera tomado en consideración por la Junta de Ampliación de Estudios que, además no tenía entre sus vocales ninguno vinculado al ámbito de la música, ni Matos era aún el hombre tan influyente que, unos años más tarde, llegaría a ser.

En septiembre de 1914 se hallaba Manuel de Falla trabajando en Siete canciones españolas, cuando al estallar la Primera Guerra Mundial, angustiado por las repercusiones que pudiera llegar a tener aquel acontecimiento, decidió regresar a Madrid. ¿De qué viviría Manuel de Falla en Madrid? Realmente ni él mismo lo sabía, a tenor de la carta que el 9 de agosto de 1914, unos días después de estallar la guerra, le es-

\footnotetext{
${ }^{9}$ Carta de 17-1-1908. SOPEÑA, Federico: Vida y obra de Manuel de Falla, Madrid, Turner, 1988, p. 51.

${ }_{10}$ Amós Salvador Rodríguez era un profesor universitario vinculado a la Institución Libre de Enseñanza, que ocupó el cargo de ministro de Instrucción Pública desde el dos de enero al 3 de abril de 1911. Su hijo, al que Matos le pide que le escriba, era Amós Salvador Carreras, más comprometido con el republicanismo, que fue ministro de Gobernación con el Frente Popular, desde el 19 de febrero hasta el 13 de mayo de 1936.

${ }^{11}$ AMF, carpeta 7.265/1.

${ }^{12}$ AHLP. Fotocopia en AMF, carpeta 7.265/2.
} 
cribe a Leopoldo Matos, en la que deja clara su postura ante la misma y su lealtad a lo que, en el ámbito de la libertad, venía a representar entonces Francia:

\begin{abstract}
"¡Viva nuestra raza, la inmortal, la grande! ¡Abajo los teutones, vergüenza de Europa! ¡Cómo corren, cómo corren los que ayer tronaban tan fuerte! Germán y yo pensábamos enrolarnos como voluntarios franceses por lo mucho que debemos (y yo sobre todo), a esta querida tierra de Francia; pero hemos tenido que desistir fundado en la triste suerte que esperaba a nuestros padres y hermana si los abandonábamos. Siendo así no podemos continuar en París, pues aquí todo está paralizado y no tendríamos ni para vivir nosotros y mucho menos los nuestros. Saldremos en el primer tren posible, que tardará aún algo porque con la movilización son muy difíciles las comunicaciones".
\end{abstract}

Falla informó a Matos que le había escrito a su antiguo profesor José Tragó una carta rogándole "me procure algunas lecciones de piano, harmonía [sic] o composición con las que poder ir tirando hasta el estreno en Madrid de la Vida Breve, que será el 4 de noviembre en la Zarzuela". Y más aún, añade:

"A Lara le escribo por este mismo correo y le ruego, como hago a ti ahora, por si les es posible a Vdes. me consigan alguna lecioncilla, y si esto no es fácil, como mucho me temo, alguna ocupación productiva, como escribiente, empleado, dependiente de escritorio o tienda. En fin [aclara Falla para que no haya duda de su actitud y su situación] estoy dispuesto a trabajar en cualquier cosa. Lo que digo a Pepe Lara te repito a ti, ya que confío en tu hermosa amistad para que pudiera encontrarme algo de qué vivir y puedan vivir los míos. Así el alma te lo agradecerá”.

Finalmente, Falla le decía que iba a escribir también a Ángel Guerra "13 “esperando que, aunque nunca me escribe, se acuerde aun de nuestra ya vieja amistad". Falla, en este impresionante documento, recurre, en fin, a todas sus antiguas amistades en Madrid, para encontrar en la capital de España un medio de subsistencia, sin poner condiciones respecto al mismo porque, dada su situación, consideraba que no estaba en condiciones de hacerlo. No es fácil imaginarse a Falla como dependiente de una tienda de tejidos o en el despacho de un negocio de ultramarinos, pero hasta ese extremo tenía dudas de que pudiera realmente llegar a sobrevivir en España.

Matos le gestionó algunas ayudas del Ministerio de Instrucción Pública, como una que se le concedió de 300 pesetas en diciembre de 1914. La gratificación fue el resultado, más o menos ficticio, de la elaboración por parte de Manuel de Falla de un estudio especial sobre "La creación de una clase auxiliar de técnica musical en el Conservatorio Nacional de Música y Declamación"14. No fue la única ayuda que Matos le gestionó. En marzo de 1915 el Subsecretario de Universidades le comunicaba

${ }^{13}$ Ángel Guerra, pseudónimo de José Betancort Cabrera fue un conocido periodista, escritor y político canario que vivió entre 1874 y 1950.

${ }^{14}$ AMF, carpeta 8.937. Documentos sobre Becas. Oficio del Subsecretario de Universidades, 30$12-1914$ 
la concesión de otra ayuda de 400 pesetas para la elaboración de un estudio sobre "Modificaciones prácticas en la enseñanza de armonía y composición"15.

El 2 de agosto de 1915 Falla, que acompañando a Gregorio Martínez Sierra y María Lejárraga estaba pasando unos días en Barcelona, le escribió a Leopoldo Matos "por si puede hacerse algo en el asunto de que me hablaste para los meses de verano en la Escuela cuya junta directiva presides, pues siendo así me iría a esa en cuanto fuese necesario, volviéndome a Barcelona después de terminar ese pequeño curso veraniego". Y añade: "Ya sabes que estoy dispuesto a hacer cuanto sea preciso para obtener unas medallitas", refiriéndose, metafóricamente, a pesetas ${ }^{16}$. Matos le escribió a Barcelona el 10 de agosto abriéndole su cartera: "Si tienes algún apuro económico, dímelo con franqueza. Ya sabes que mi bolsa es tuya""17.

Como resultado de estas eficaces gestiones, en octubre del mismo año la Subsecretaría de Universidades le volvió a encargar otro trabajo, ahora sobre "Enseñanza de la Música extranjera en el Conservatorio Nacional"18. Pocos días antes Matos le daba la agradable noticia de la inminente firma por el ministro de aquella Orden por la que se le abonarían "300 medallas"19, que debieron estar disponibles a finales de diciembre de aquel año, 1915, cuando Matos le dice: "Ya debe estar ahí el giro de la memoria. Cóbralo y queda terminantemente prohibido que me lo entregues. No sólo no lo recibiría, sino que el solo intento de oferta me causaría hondo agravio y traería quebranto de nuestra amistad", en clara referencia a la deuda material que Falla tenía ya contraída con Leopoldo Matos quien, entretanto, le confirma su intención de seguir ayudándole: "Espero que para el mes próximo podré sacar un piquillo de Instrucción Pública"20.

La prolongación de la guerra mundial impedía la normalización económica de Fa1la, que seguía necesitando de estas ayudas que le gestionaba su amigo Matos quien el 7 de septiembre de 1917 le escribía, ahora como Gobernador Civil de Barcelona, y le informaba que había hablado con Bullón, de la Junta para la Ampliación de Estudios y que habían acordado convertir la memoria necesaria para una nueva subvención en tres conferencias que le pagarían en el momento que presentase tres certificados de haberlas dado en cualquier centro de Madrid o provincias y, con cierta modestia, añadía: "el caso tuyo actual debe haberse dado infinitas veces pues no serán pocos los amigos de Ministros y Directores que habrán cobrado por anticipado esta labor, pero yo en realidad no se qué resortes hay que tocar para obtener tales certificados" 21 . En realidad, le estaba filtrando que se buscara un amigo que le firmara los papeles porque las conferencias, como era habitual en aquel mecanismo burocrático y artificioso, no había que impartirlas. No consta que Falla diera esas conferencias y dados los escrú-

${ }^{15}$ AMF, carpeta 8.937. Documentos sobre Becas. Oficio del Subsecretario de Universidades de 13-4-1915.

${ }^{16}$ AHLP. Fotocopia en AMF, carpeta 7.265/2.

${ }^{17}$ GALLEGO, Antonio: Manuel de Falla y El amor brujo, Madrid, Alianza Editorial, 1990, pp. 60-61.

18 AMF, carpeta 8.937. Documentos sobre Becas. Oficio del Subsecretario de Universidades de 20-10-1915.

19 AMF, carpeta 7.263/1. Carta de Leopoldo Matos de 8-10-1915.

${ }^{20}$ AMF, carpeta 7.265/1. Carta de Leopoldo Matos de 21-12-1915.

${ }^{21}$ AMF, carpeta 7.265/1. 
pulos morales que conformaban su personalidad, es dudoso que llegara a cobrar este importe.

En febrero de 1919 Matos le gestionó otra ayuda, en la que Falla solicitaba una subvención de 1.500 francos para permanecer tres meses en París realizando en las bibliotecas y archivos de dicha capital estudios sobre música francesa antigua y moderna $^{22}$. Era también un formulismo habitual para el que Matos le envió incluso la instancia y la memoria ya redactadas para que Manuel de Falla se limitara a firmarlas y le informaba que, al enviarla, le escribiría a Mariano Benlliure, presidente ahora de la Junta de Ampliación de Estudios, "recordándole la promesa que nos tiene hecha"23. En fin, que todo se movía en esta confusa maraña de teclas desafinadas que Falla no controlaba con precisión y que, en algunos casos como éste, no llegaron a dar buen resultado.

Sí lo dio una última gestión de Matos por la que Falla recibió una nueva beca de 500 pesetas del Ministerio de Instrucción Pública y Bellas Artes para la realización de un trabajo titulado "Estudio de la Orquesta moderna en los cursos de composición musical de los Conservatorios Nacionales" que, según la documentación oficial, Falla se apresuró a entregar y a cobrar ${ }^{24}$.

La situación económica de Falla era ciertamente precaria, si bien de la misma vino a salvarle providencialmente una singular iniciativa del duque de Alba que, informado de la situación del compositor, movilizó a la nobleza española a favor de don Manuel, tal vez como desagravio a la denegación de pensión que Falla había solicitado a la Junta para Ampliación de Estudios. El hecho es que el duque inició en el mes de mayo de 1919 una cuestación a favor de Manuel de Falla en la que participaron 37 pudientes, la mayoría miembros de la nobleza, que proporcionó al músico ocho mil pesetas, equivalentes a unos 17.000 euros en valores constantes a enero de $2011^{25}$. Aquel dinero no fue entregado a Falla de manera global sino que fue depositado en el Banco Urquijo para que éste dispusiera del mismo mediante mensualidades de 500 pesetas, que Falla podría cobrar durante 16 meses, es decir, hasta octubre de 1920. Es esclarecedor de todo ello la carta que el duque de Alba le envía desde el Senado:

"Ha sido para mí muy grato poderle prestar este modesto servicio que espero ha de contribuir a facilitarle los medios de vida durante esos meses malos, porque pronto la música genial que V. compone ha de darse más a conocer aún, y no le será a V. precisa ayuda alguna" ${ }^{26}$.

Así fue. Para esa fecha, terminada ya la Primera Guerra Mundial la situación de los derechos de autor con su editor francés, Max Eschig, había quedado normalizada y Falla decidió distribuir la edición de sus obras sucesivas entre éste y la casa Chester

${ }^{22}$ Al cambio de 72,66 pesetas los cien francos vigente ese año, la petición equivalía a 1.090 pesetas corrientes, 2.302 Euros en valores constantes a enero de 2011.

${ }^{23}$ AMF, carpeta 7.265/1. Carta de Leopoldo Matos, 25-2-1919.

${ }^{24}$ AMF, carpeta 8.937. Resolución del Ministerio de Instrucción Pública, 16-8-1919 y 25-8-1919.

${ }^{25}$ AMF, carpeta 6.681.

${ }^{26}$ AMF, carpeta 6.681. Carta del duque de Alba a Manuel de Falla, 9-6-1919. Otras cartas en el mismo sentido, 16 y 18-6-1919. 
de Londres, así como poner orden en los derechos que le habrían de llegar a través de la Sociedad de Autores Españoles, lo que permitió al músico percibir unos honorarios decorosos, mantener su independencia económica y vivir con un cierto desahogo que utilizó para hacer realidad uno de sus sueños: trasladarse a vivir a Granada para dedicarse desde el aislamiento, el silencio y la soledad a crear una música nueva que su talento vislumbraba entonces con meridiana claridad. Falla cumplió aquel propósito y junto a la Alhambra residió durante 19 años, desde finales de septiembre de 1920 hasta las mismas fechas de 1939, poco después de terminar la guerra española y recién empezada la II Guerra Mundial.

\section{La República no es quemar iglesias}

Falla se hallaba en la cumbre de su madurez artística y Granada le aportaba la paz y el equilibrio ambiental del que había carecido hasta ahora, convirtiéndole, en expresión de Orozco, en un "granadino inconfundible [...] En Granada Falla vive más cerca del pueblo, más intensamente la sencillez de la gente y sus problemas. Ya será don Manuel en una ciudad donde todos le conocen y le estiman". Y los hermanos Falla se ven conquistados desde su aparición en Granada por "el cariño y la estimación de una ciudad y de una generación granadina importante"27, que formó un grupo de incondicionales en torno a ellos rodeándoles de afecto y de cariño desde el principio y ayudándoles en todo cuanto pudieran necesitar ${ }^{28}$. El 11 de diciembre de 1922 y tras un inolvidable viaje a Granada, Wanda Landowska le escribía a Falla: "Le ruego diga a los jóvenes poetas y artistas que le rodean y forman una amable corte en torno a usted, que conservo el más simpático recuerdo de ellos"29.

¿Quiénes eran aquellos jóvenes poetas y artistas a los que se refiere Landowska? Orozco los catalogó al afirmar que estamos ante la generación granadina de la vanguardia y su nómina es rica en inquietudes literarias y artísticas que en torno a las descomunales figuras de los hermanos García Lorca, Francisco Soriano Lapresa, José Fernández Montesinos, Melchor Fernández Almagro, José Mora Guarnido, Constantino Ruiz Carnero, Ramón Pérez Roda, Miguel Pizarro, José Navarro Pardo, Ángel Barrios, y los pintores José María Rodríguez-Acosta y López Mezquita, Gabriel Morcillo, Manuel Ángeles Ortiz, Ismael González de la Serna, Hermenegildo Lanz y los escultores Pablo Loyzaga y Juan Cristóbal. Todos ellos, guías generacionales de la juventud universitaria en la que figuras del pensamiento como Enrique Gómez Arboleya, Joaquín Amigo, Luis Jiménez, Manuel López Banús, Francisco Ayala, Francisco Cirre, se integran en la vanguardia que se va a expresar en la revista

${ }^{27}$ OROZCO DÍAZ, Manuel: Falla: biografía ilustrada, Barcelona, Destino, 1968, p. 109.

${ }^{28}$ GARCÍA, Juan Alfonso: Falla y Granada y otros escritos musicales, Granada, Centro de Documentación Musical de Andalucía, 1991, p. 31.

${ }^{29}$ NOMMICK, Yvan: "Manuel de Falla, un músico universal en Granada", en Manuel de Falla en Granada, Granada, Publicaciones del Archivo Manuel de Falla, 2001, p. 77. 
Gallo. No pudo encontrar en toda la geografía española un lugar mejor para él como aquella Granada febril e ilusionada ${ }^{30}$.

Quienes conozcan la historia de Granada podrán observar en la nómina anterior gente de muy distintas adscripciones políticas. Personas que pagaron su compromiso izquierdista o simplemente republicano con la muerte, la prisión, la amenaza, el chantaje o el exilio, junto a otros que no tuvieron que vivir ninguna de dichas circunstancias y que, con mejor que peor grado, convivieron con el régimen que surgió de la Guerra Civil.

Posiblemente lo que mejor pueda expresar esta posición de Falla por encima de cualquier adscripción ideológica sea la petición de ayuda que realizó a Leopoldo Matos, claramente posicionado con los planteamientos monárquicos y derechistas, a favor de Fernando de los Ríos, el hombre del Partido Socialista Obrero Español en Granada.

En la carta que Falla escribió a Leopoldo Matos el último día del año 1930 le preguntaba sobre un rumor: "Por cierto que el otro día me dijo (Segura) que tu nombre sonaba insistentemente para cierta combinación ministerial que, en sourdine, se viene anunciando para más o menos pronto. No quiero hacerte preguntas indiscretas, pero ya supondrás mi grandísimo interés por tenerlas" ${ }^{31}$. Algo que efectivamente ocurrió porque tres días después, el 3 de enero, Leopoldo Matos era nombrado ministro de Fomento en el Gobierno formado por el general Dámaso Berenguer, primero tras la dimisión de Primo de Rivera. Matos sería luego nombrado ministro de Gobernación en aquel Gobierno y el encargado, por consiguiente, de llevar a cabo unas elecciones generales que nunca se pudieron realizar.

Las cartas entre ambos amigos a partir de entonces están cargadas, junto al afecto de siempre, de un apartado de recomendaciones de Falla para su amigo: puestos vacantes, oposiciones, tribunales..., claros ejemplos de que la bondad de don Manuel no podía sustraerse a atender las demandas de influencia de quienes le rodeaban; personas casi desconocidas, amigos de los amigos, pero también otros más cercanos, como cuando Pedro Borrajo, que tanto ayudaría Falla y a su hermana, le pide una recomendación para ocupar el cargo de Depositario en la Diputación Provincial. Por lo singular del caso, resulta oportuno destacar la intervención de don Manuel a favor de Fernando de los Ríos para la obtención de una plaza de catedrático en la Universidad Central.

Fernando de los Ríos había ganado la cátedra de Derecho Político de la Universidad de Granada en 1911. La ejerció, compatibilizándola con su actividad política y sus numerosos viajes hasta que el 18 de marzo de 1928 renunció a ella en solidaridad con la destitución del profesor García Labella y le fue devuelta por el Gobierno de Berenguer a finales de enero de 1930 junto con la de los profesores José Ortega y Gasset, Luis Jiménez de Asúa, Felipe Sánchez Román y Alfonso García Valdecasas,

${ }^{30}$ OROZCO DÍAZ, Manuel: Granada y Manuel de Falla, Granada, Fundación Caja Granada y Ayuntamiento de Granada. Colección "Personajes y temas granadinos", 1996, p. 13.

${ }^{31}$ AHLP. Fotocopia en AMF, carpeta 7.265/2. Carta de Manuel de Falla, 31-12-1919. 
en un momento en que el duque de Alba desempeñó interinamente la cartera de Instrucción Pública ${ }^{32}$.

La oposición para la cátedra de la Universidad de Madrid se había discutido en el Consejo de ministros el 27 de julio de 1930 pero el ahora ministro de Instrucción Pública, Elías Tormo, encontró algunas resistencias en el Consejo. Finalmente, con la inestimable ayuda de Matos, la convocatoria se publicó el 28 de agosto y Fernando de los Ríos, que siempre se consideró "en tránsito" en Granada, la firmó. Falla le escribió entonces a su amigo Matos:

"Querido Leopoldo: Ya conoces la mucha estima en que tengo a Fernando de los Ríos y la excelente amistad que nos une desde que vine a Granada. De él hemos hablado tú y yo en más de una ocasión y tú has compartido esos sentimientos. También conoces el asunto de la cátedra de Madrid. Él me acaba de hablar sobre ello a su paso por Granada y por él sé que la excelente actitud de Tormo con respecto a él en uno de los últimos Consejos, no parece que fue secundada por alguno o algunos de los demás ministros y esto es lo que vengo a pedirte: que apoyes a Tormo cuando se vuelva a tratar del asunto... Lo demás tu ya lo sabes mucho mejor que yo" ${ }^{\text {"33. }}$.

Y Matos, siempre comprensivo y colaborador, le contesta que Fernando de los Ríos tiene todos sus respetos, simpatía y admiración: "Su competencia en la materia que será objeto de sus investigaciones y estudios en Madrid de todos es conocida y envidiada. Lo que te digo parte para que comprendas que habré de poner todos los medios que estén a mi alcance para que el pensamiento de Tormo tenga realidad" ${ }^{34}$. El resultado fue satisfactorio y Fernando de los Ríos se convirtió en catedrático de "Estudios Superiores de Ciencia Política y Derecho Político" de la Universidad Cen$\operatorname{tral}^{35}$. Parece claro que, aparte de su valía intelectual, la gestión de Falla con Matos y de éste con Tormo y con el resto de los ministros debió contribuir eficazmente a aquel resultado.

No fue posible la celebración de las elecciones generales que se propuso el Gobierno de Berenguer, dimitió éste y con él Matos, el ministro amigo de Falla, y le sucedió el almirante Juan Bautista Aznar quien convocó unas elecciones municipales que se celebraron el día 12 de abril de 1931, cuyo resultado propició la proclamación, el 14, de la Segunda República Española.

Manuel de Falla se encontraba en Granada y su amigo, el crítico musical John B. Trend le escribía entusiasmado: “ $i Q u e ́$ tiempos históricos que estamos viviendo! ¡Y todo se ha pasado con más tranquilidad y orden y disciplina que la misma Escandinavia de hace veinte años, cuando se separaba Noruega de Suecia!" ${ }^{36}$. Y don Manuel, que medio en broma medio en serio hablaba ya en 1911 con su amigo Leopoldo

${ }^{32}$ RUIZ-MANJÓN, Octavio: Fernando de los Ríos. Un intelectual en el PSOE, Madrid, Síntesis, 2007, pp. 285, 296 y 302.

${ }_{33}$ AHLP. Fotocopia en AMF, carpeta 7.265/2. Carta de Manuel de Falla, 7-8-1930.

${ }^{34}$ AMF, Carta de Leopoldo Matos, 14-8-1930.

${ }^{35}$ RUIZ-MANJON, O.: Fernando de los Ríos..., pp. 31 y 315.

${ }^{36}$ Carta de 25-4-1931. FALLA, Manuel de y TREND, John B.: Epistolario (1919-1935), Granada, Universidad de Granada y Archivo Manuel de Falla, edición de Nigel Dennis, 2007, p. 187. 
Matos de dicha posibilidad, le respondía lacónico y complacido por la forma en que habían acontecido los hechos, pero dejando entrever que temía un nuevo rumbo para un cambio que él califica de revolucionario: "Realmente ha sido maravilloso el modo de efectuarse la revolución. Dios quiera que siga su marcha normal por el mismo sereno camino" 37 .

No conocía aún Manuel de Falla lo que le había ocurrido aquellos días a Matos, de lo contrario no hubiera estado tan complaciente con Trend. Y es que la adscripción monárquica que Leopoldo Matos mantuvo durante toda su vida y su activa participación en el Gobierno Berenguer hicieron que al proclamarse la II República lo pasara realmente mal, que estuviera a punto de perecer en el asalto realizado al Círculo Monárquico Independiente de Madrid el 10 de mayo de 1931 y que, finalmente, tuviera que huir del país. Con este descorazonamiento escribe a Falla desde el "Grand Hotel et Bellevue Palace" de París:

"Recibimos el telegrama de María del Carmen y lo contesto después de pasar la frontera echado de mi país por la violencia de los mayores ultrajes y feroces agresiones que un hombre puede recibir, sin que durante mi calvario tuviese a mi lado ni siquiera la protección de la autoridad y del poder. Tres horas entregado a unas turbas"38.

Pronto pudo comprobar Falla que el camino emprendido por la República no era el que a él, profundamente religioso, le gustaba y no dudó en manifestar su consternación por el tratamiento que comenzó a recibir la Iglesia católica por parte del nuevo Gobierno republicano y de las masas populares, que aprovechaban sus reivindicaciones sociales para arremeter contra las iglesias y los conventos ${ }^{39}$. El 20 de mayo se lo confirmaba a Trend: "Estos días - desde los recientes sucesos que conocerá usted por la Prensa- cuentan entre los más amargos de mi vida"40. Así se lo había hecho saber al presidente de la República, Niceto Alcalá Zamora, en un telegrama que, junto con otros amigos granadinos, le dirigió el 14 de mayo:

Grupos no numerosos han estado dos días cometiendo en la ciudad toda clase de sacrilegios, atropellos a domicilios religiosos e insultos a sus personas, sin eficaz intervención autoridades. A V. Respetuosamente, como representante supremo Poder, acudimos con nuestra información y nuestra indignada protesta ${ }^{41}$.

${ }^{37}$ Carta de 4-5-1931. FALLA, M. y TREND, J.B.: Epistolario..., p. 189.

38 AMF, carpeta 7.263/2. Carta de Leopoldo Matos, 27-5-1931. Una descripción de estos acontecimientos en TITOS MARTÍNEZ, M.: Música y finanzas... pp. 144-146.

${ }^{39}$ Una descripción de los ataques producidos contra instalaciones religiosas en Granada en la primera manifestación de hostilidad durante la República, en mayo de 1931, puede verse en TITOS MARTÍNEZ, Manuel; VIÑES MILLET, Cristina y GAY ARMENTEROS, Juan: Medio siglo de vida granadina: en el cincuentenario de Ideal (1932-1982), Granada, Universidad, 1985, pp. 67-72.

${ }^{40}$ Carta de 20-5-1931. FALLA, M. y TREND, J.B.: Epistolario..., p. 191.

${ }^{41}$ AMF, carpeta 6.788. Encabeza las firmas Manuel de Falla y le siguen Ramón Pérez Roda, Francisco González Méndez, José María Bérriz, Eusebio Borrajo, José Segura, Emilio García Gómez y Hermenegildo Lanz. 
Y así le hizo llegar también su opinión a Fernando de los Ríos, nombrado ahora ministro, a quien le decía:

"Estoy absolutamente seguro que de haber estado usted en Granada, hubiera bastado su gran autoridad moral para evitarlos [...] Los sucesos han dejado, entre otros sedimentos, una impresión de desamparo que, unida a la actitud de cierta parte -aunque ínfima- del pueblo, hace temer a algunos religiosos por su seguridad personal, y así me lo manifiestan para prevenirle a usted, conociendo la amistad que felizmente nos une" ${ }^{" 42}$.

Helen Nicholson, baronesa de Zglinitzki y suegra del catedrático de la Universidad de Granada Alfonso Gámir Sandoval, a quien sorprendió el comienzo de la Guerra Civil en Granada y publicó al año siguiente un libro con su testimonio de aquellos días, recogió esta sensación de pesimismo que embargaba a Falla entonces por estos ataques contra los símbolos religiosos que eran sagrados para él:

"Abril y mayo pasaron volando como en encantadas alas. Llegué a escuchar terribles predicciones sobre el destino de España pero apenas les presté atención, pues estaba demasiado embelesada absorbiendo la luz y el color de mi alrededor. Estaba, podría decirse, emborrachada de belleza. Una visita a mi viejo amigo Manuel de Falla logró abrirme los ojos a la verdad, pues aunque él rehusaba conversar de política, no pude evitar ver cómo los problemas del país se habían cebado con su mente y destrozado su frágil constitución. Este hombre de gran corazón que le ha dado al mundo tan excelsa música cede a los pobres de Granada el dinero que ésta le proporciona, mientras él vive casi en la pobreza. Como santo y místico que es, profetizó, creo que con más claridad que ningún otro, el martirio que España pronto habría de sufrir. Hablaba de los actos de blasfemia que ya se estaban cometiendo -incendios de iglesias y profanación de sagradas reliquias- y me di cuenta de la angustia que suscitaban en él tales sucesos. - ¿Cuál puede ser el futuro de España mientras este negro nubarrón se ciñe sobre nosotros? -decía" ${ }^{\prime 3}$.

La preocupación de Falla por el tratamiento del problema religioso siguió teniendo como confidente de sus amarguras y destinatario de sus protestas a Fernando de los Ríos. El 23 de enero de 1932, tras la aprobación por el Gobierno de una circular en la que ordenaba la retiraba el crucifijo de las escuelas y de un proyecto de ley sobre secularización de cementerios, Falla le escribió lamentando que se quisiera confundir la posición anticlerical con una ofensiva anticristiana y que no se tuviera con los católicos "siquiera el mismo respeto que se concede a la de los moros y judíos de Marruecos". Recuérdese que el norte de Marruecos era entonces una colonia española, en régimen de protectorado. Más adelante añadía: "El estado castiga severamente la

${ }^{42}$ Cartas de 19 de junio y 13 de agosto de 1931, en Poesía. Revista ilustrada de información poética 1991: 220. También en RUIZ-MANJÓN, O.: Fernando de los Ríos..., p. 332.

${ }^{43}$ NICHOLSON, Helen: Death in the Morning, London, Lovat Dickson Limited Publishers, 1937, pp. 13-14. Edición en español, Muerte en la madrugada, Granada, editorial Atrio, 2007, edición y estudio preliminar de C. VIÑES MILLET. 
rebeldía contra sus leyes, pero deja impune, y hasta cierto modo, a veces, estimula la rebeldía cuando se manifiesta contra Dios y contra la Doctrina de Cristo"44.

Unos meses más tarde y en el contexto de las algaradas y manifestaciones que en todo el país se produjeron a propósito del intento de golpe de Estado del general Sanjurjo ${ }^{45}$, Falla le escribía:

"al producirse el insensato movimiento político-militar que ha dado origen a los hechos en cuestión, yo he sido uno de los primeros en condenarlo; pero no es menos insensato lo que ha ocurrido en Granada, donde aquel movimiento no ha tenido la menor repercusión. Y es tristísimo que, siquiera fuese en apariencia, quienes han debido velar por el orden y la justicia se hayan cruzado de brazos, y sólo tardíamente hayan creído deber dar la impresión de que existían. Digo a usted todo esto, no sólo como leal información al amigo querido, sino también al hombre responsable del Gobierno de España, y como protesta (respetuosa, pero noblemente indignada como cristiano, como español y como artista por mi oficio) ante cuantos como usted comparten aquella tremenda responsabilidad" ${ }^{\prime 6}$.

Realizó aquel año 1932 Manuel de Falla un viaje a San Sebastián y a Venecia, para atender algunos compromisos artísticos. La primavera de 1933 la pasó en Mallorca a donde volvió para permanecer durante casi todo el primer semestre de $1934^{47}$. Cuando regresó finalmente a Granada su salud estaba seriamente quebrantada y a partir del verano de 1934 renunció ya genéricamente a las invitaciones que le llegaban de París y de Londres para nuevas representaciones de sus obras. Pero en determinadas épocas Granada ya no le daba la paz y el recogimiento que el músico necesitaba, de manera que buscó refugio en otros lugares que le facilitaban sus amigos: Lanjarón, La Zubia e, incluso, en una finca llamada Huerta Chica situada en la sierra de Córdoba, aunque en una situación cada vez más recluida. Walter Starkie, que lo visitó en 1935 dijo que "aquel intelectual enfrentado a un tropel de demonios andaluces" que era Falla en 1921, se había convertido ahora en "un monje ascético, cuya vida se desarrollaba entre meditaciones en su celda y ensueños en su jardín. Ya no aspiraba sino a la paz y el recogimiento" 48 .

Entretanto, su amigo Matos había regresado a España donde pudo reemprender su actividad jurídica; la última carta conservada que Falla le escribió personalmente, está fechada en mayo de 1935 y es para interesarse sobre los rumores circulantes acerca de la implicación judicial de Matos en el proceso sobre la sublevación de Jaca y la ejecución de sus autores y para invitarle a ir a Granada para conocer la Salve

\footnotetext{
${ }^{44}$ RUIZ-MANJON, O.: Fernando de los Ríos..., p. 349

${ }^{45}$ Una descripción de aquellas jornadas en Granada puede verse en TITOS MARTÍNEZ, M. y otros: Medio siglo de vida granadina..., pp. 115-123.

${ }^{46}$ RUIZ MANJÓN, O.: Fernando de los Ríos..., pp. 359-360.

${ }^{47}$ Desde Mallorca escribió Falla a Alcalá Zamora un nuevo telegrama el 1 de junio de 1933 suplicándole "no sancione Ley Confesiones Congregaciones que confirma implacable designio descristianización España". AMF, carpeta 6684.

${ }^{48}$ STARKIE, Walter: Espagne. Voyage musical dans le temps et l'espace, Paris, René Kister, 1959, p. 150, citado en Poesía. Revista ilustrada de información poética (1991) p. 231.
} 
en el Mar, "que es lo último que he hecho" "49. En su respuesta, el interés principal de Matos era dejar tranquilo a su amigo. Efectivamente, había sido encausado por la Comisión Parlamentaria creada para dilucidar las responsabilidades por la represión de la sublevación republicana de Jaca en diciembre de 1930, pero al pasar el asunto al Tribunal Supremo fue citado únicamente como testigo y allí lo único que hizo fue solidarizarse, como ministro, con la conducta del presidente del Consejo. Felizmente -le dice- la justicia se ha hecho y el Tribunal ha dictado una sentencia absolutoria completa y total. Se trata pues -le confirma- de un asunto completamente liquidado.

La siguiente comunicación de Matos es de mitad de marzo de 1936, un mes después de producirse el triunfo del Frente Popular en las elecciones de febrero anterior, que marcaron un nuevo rumbo para la República y para el futuro del país. La carta se mueve entre el lirismo y la tragedia:

"Querido Manolo: no puedo separar tu persona y tu recuerdo de la inmensa "tragedia". ¡Noches en los jardines de España! ¡El Generalife, Dauro Lejano! En forma de ilusión entró en tu alma la sensación que recibieron pisando esa tierra maravillosa, pintores y poetas y devolviste la sensación sin conocer la realidad, en tu música maravillosa. ¿Quién te salvará? ¡iEl Altísimo!! Así decías y la máxima emoción más que al emitir la voz al pulsar las gigantescas notas, te ahogaba y nos asomábamos al balcón: luna, campanas, olor de Alhambra y el inexplicable ruido de Granada, murmullo de oraciones infantiles ¿Te acuerdas?

¡Qué infamia! Voces de odio, humo que ahoga, llamas que profanan, tiros de arma corta y villana... y te veo en tu Antequeruela buscando con la mirada en el cielo refugio contra los horrores de la tierra. ¿A qué seguir? Un fraternal abrazo. Leopoldo" 50 .

La depresión que Matos suponía y que los acontecimientos habían producido en la vida de don Manuel era real, hasta el punto de que las siguientes cartas a su querido Leopoldo, ya no las escribe Manuel sino que lo hace en su nombre y por razones de enfermedad, su hermana María del Carmen. El pretexto es encargarle algunas partituras. El texto es pedirle, encarecidamente, que venga a verlos, tal como les había prometido. Falla necesita ver a su amigo en aquellos momentos de incertidumbre y así se lo dice a través de la correspondencia, labrada con mano firme sobre el papel, que le escribe su hermana ${ }^{51}$.

No fue posible cumplir aquel deseo. En la última carta que Matos escribió a Falla, fechada el 21 de junio de 1936, se lamentaba de no haber podido pasar con él aunque hubieran sido solo unas horas, pero confiaba en que muy pronto le iban a señalar una vista en la Audiencia de Granada y aprovecharía entonces para desquitarse de tan larga soledad. Y al final de la carta, que va escrita a máquina, Matos no se resiste a tomar la pluma y añadir como postdata las últimas palabras que escribió para don Manuel.

${ }^{49}$ AHLP. Fotocopia en AMF, carpeta 7265/2. Carta de Manuel de Falla, 17-5-1935. Citada por DE PERSIA, Jorge: Los últimos años de Manuel de Falla, Madrid, Sociedad General de Autores Españoles, 1993, p. 207 ( $1^{\mathrm{a}}$ ed. 1989).

${ }^{50}$ AMF, carpeta 7.263/2. Carta de Leopoldo Matos, 17-3-1936.

${ }^{51}$ AHLP. Fotocopia en AMF, carpeta 7.265/1. Cartas de María del Carmen Falla, 23-4-1936 y 3-6-1936. 
Palabras que reiteran su decepción política y, tal vez, una cierta complicidad, o al menos información sobre los acontecimientos que se avecinaban, pero que contienen también la reiteración de su ofrecimiento leal y sincero para cuanto el músico, en el ámbito terrenal, pudiera necesitar:

\begin{abstract}
"Tenía mi viaje por objeto no solo la satisfacción de verte, sino la de conocer tu administración y caja, pues las convalecencias encarecen la vida y disminuyen los rendimientos del trabajo; les fronts populaires hispano-franceses no están para músicas; y a veces se alcanza un rápido restablecimiento más con curas de reposo que con medicina. Y como todo esto, por su carácter extraordinario, exige gastos extraordinarios y en buena doctrina económica a esto se atiende con empréstitos, aquí vengo yo, en forma de banquero para nutrir tú cuenta corriente con lo que te haga falta. Y no me llames Samuel, porque procuraré olvidarme de esa carta a la que tu tanto amas. En serio, querido Manolo, dime si algo necesitas" ${ }^{\prime 52}$.
\end{abstract}

Este fue, en fin, el amigo que tanto quiso a Falla y que tan admirablemente fue correspondido, hasta el punto que fue uno de los pocos que pudo escuchar trozos de "Atlántida" al piano, interpretada directamente por su autor, antes de la marcha a Argentina de don Manuel ${ }^{53}$. Matos fue una figura muy relevante en el ámbito político de la Restauración; era titular de un bufete de abogados en Madrid. Además, fue diputado por Las Palmas desde 1910 a 1923; gobernador civil de Barcelona, nombrado por el Gobierno de Eduardo Dato durante la importantísima crisis del verano de 1917 cuando le tocó disolver la Asamblea de Parlamentarios reunida en la Ciudad Condal al margen de las Cortes; ministro de Trabajo con Antonio Maura en 1921; ministro de Fomento y de Gobernación con Dámaso Berenguer en 1930-31; encargado de realizar las elecciones generales que nunca llegaron a tener lugar; y amigo personal de Alfonso XIII, que le encargó la testamentaría de su propia madre, la reina María Cristina. Con ese currículum, Matos podía ayudar mejor que nadie a Manuel de Falla a desenvolverse en un mundo que para él era una auténtica tortura. Como tortura debió ser la noticia de su terrible muerte.

El triunfo de la candidatura de derechas en Granada en las elecciones de febrero de 1936 movilizó a los "frentepopulistas" granadinos que consiguieron que el Congreso anulara las elecciones y acordara una segunda vuelta que cambió radicalmente la representación provincial ${ }^{54}$. Pero la movilización dejó trágicas secuelas en la ciudad: fueron quemados el teatro Isabel la Católica, los cafés Colón y Royal, los talleres del periódico de la CEDA, Ideal, varias fábricas y comercios, las instalaciones de la Sociedad de Tenis, las iglesias de El Salvador, San Cristóbal, San Gregorio el Bajo, el convento de San Gregorio el Alto, se saquearon las sedes de Falange, Acción Popular, Acción Obrerista y numerosos edificios particulares ${ }^{55}$.

\footnotetext{
${ }^{52}$ AMF, carpeta 7.263/2. Carta de Leopoldo Matos, 21-6-1936.

${ }^{53}$ SOPEÑA, F.: Vida y obra de..., p. 211.

${ }_{54}$ ÁlVAREZ TARDÍO, Manuel y VILLA GARCÍA, Roberto: El precio de la exclusión. La política durante la Segunda República, Madrid, Encuentro, 2010, principalmente "Granada en las elecciones del Frente Popular", pp. 250-283.

${ }^{55}$ TITOS MARTÍNEZ, M. y otros: Medio siglo de vida granadina..., pp. 127-134.
} 
Aquella situación movió a Manuel de Falla a dirigirse directamente al presidente de la República, Manuel Azaña. Entre ambos existía una vieja relación, aunque no frecuentemente cultivada. En 1916 Azaña había invitado a Falla a participar en algunas actividades organizadas en el Ateneo de Madrid, que él presidía. En 1920 le envió desde París un artículo que escribió en El Imparcial a propósito del estreno de "El sombrero de tres picos" en la Ópera parisina. En enero de 1921 le escribió a Granada felicitándole el año nuevo... y poco más ${ }^{56}$. Ahora, ante los acontecimientos que tuvieron lugar en Granada y en otros lugares de España, Falla se decidió a escribir a Azaña una carta emocionante:

"Mi muy distinguido amigo: Al mismo tiempo que me complazco cordialmente en felicitarle por su elevación a la Presidencia de la República, quiero manifestarle un vivísimo anhelo, en el que participan muchos miles de españoles: que veamos el final de esta etapa de amargura que sufrimos los cristianos de España a causa de la destrucción de nuestros templos, de las inmundas blasfemias públicas y colectivas comenzando por los ultrajes más horrendos al Santo Nombre de Dios, venerado hasta ahora en todos los siglos y por todos los pueblos cultos e incultos de la tierra-, y del martirio de personas que han consagrado su vida a la caridad. Por eso yo suplico, no solo al presidente de la República sino a la persona de tan fina sensibilidad literaria que siempre he considerado como amigo, que nos ayude en este trance, sirviéndose de su autoridad suprema.

Con tal esperanza le dirijo esta carta, la única que desde hace mucho tiempo escribo, a causa de una grave enfermedad, ocasionada por todos esos sacrilegios y sucesos, que ha puesto en peligro mi vida. Y esté usted absolutamente seguro de que le hablo sólo como católico, con independencia de todo interés político (que nunca he tenido) o puramente humano, cuya mezcla con la religión me ha parecido siempre reprobable" 57 .

De aquella carta acusó recibo el secretario particular del Presidente, informando a Falla que, oportunamente, daría cuenta al mismo de su contenido. No es seguro que llegara siquiera a verla. Sí lo es que no la contestó.

\section{Recluido en una Granada en guerra}

A partir del 18 de julio de 1936 Manuel de Falla unió a sus padecimientos personales el de las desgracias de sus amigos, encarcelados o asesinados al estallar la Guerra Civil. El de Federico García Lorca en Granada el 18 de agosto, por quien trató inútilmente de interceder ante las autoridades $\operatorname{locales}^{58}$ o el de Rosario Fregenal Piñar, la

\footnotetext{
${ }^{56}$ AMF, Carpeta 6732. Cartas de Manuel Azaña a Manuel de Falla, abril de 1920, 8-2-2920, 5-1-1921.

${ }^{57}$ AMF, Carpeta 6732. Carta de Manuel de Falla a Manuel Azaña, 23-5-1936.

${ }^{58}$ Tras la primera "visita" de amenaza que la familia de Federico García Lorca recibió en la Huerta de San Vicente, algunos pensaron que el mejor sitio para que el poeta se refugiara era la casa de Manuel de Falla. No aceptó Federico, que prefirió la casa de sus amigos falangistas los hermanos Rosales. Cuando la casa de éstos comenzó también a ser vigilada, creyeron que el sitio más seguro era el Carmen de La Antequeruela, algo que no es seguro que hubiera resultado efectivo ante la barbarie
} 
Fregenala, que había sido costurera de su hermana Carmen y cuya mediación resultó igualmente infructuosa ${ }^{59}$. Pero también el de su más íntimo amigo, Leopoldo Matos Massieu, asesinado por las milicias republicanas en Fuenterrabía el 4 de septiembre. No sabemos cuándo tuvo noticia Manuel de Falla del asesinato de Leopoldo Matos, pero basta leer algunas de las últimas cartas cruzadas entre ambos, para intuir cuál pudo ser su reacción ante tal barbaridad.

Falla, abatido y desconcertado, contemplando cómo sus amigos eran asesinados por un bando y por el otro, se encerró en su Carmen negándose a recibir visitas y padeciendo una grave desnutrición. Qué efecto produjo ello en la moral del músico es algo respecto de lo que cualquier valoración puede resultar superflua. Falla no sabe bien en aquellos momentos dónde poner su corazón y su cerebro, cayendo en una profunda depresión y empeorando de sus múltiples enfermedades, de lo que tardó casi un año en recuperarse. Comenzó a sufrir un absceso tuberculoso y una artritis, también tuberculosa, de las que tuvo que ser intervenido en varias ocasiones. "La catástrofe de la Guerra Civil [escribió Francisco García Lorca], la brutal persecución y asesinatos de los que fueron sus amigos en Granada, debieron producir verdadero horror en el ánimo de Falla, ya contristado por los excesos de la tensión política que preludiaron el estallido de la guerra" ${ }^{\circ 0}$. De sus amigos de Granada, como afirma el hermano de Federico, y de fuera de Granada, porque nadie tan próximo al corazón de Manuel de Falla, como Matos, víctima también de la barbarie de la guerra. Con Federico, incluso, Falla había tenido algún momento de "desconfor" 61 , aunque de ello había transcurrido ya mucho tiempo y ahora predominaba el afecto común por encima de cualquier controversia. Con Matos, ni eso.

En Granada la vida volvió a su cauce más o menos natural a finales de 1936, la presión de la aviación republicana se detuvo, los ataques desde la periferia comenza-

desatada en aquellos momentos en Granada. "¿Quién iba a atreverse a violar la casa del maestro [se pregunta Gibson] compositor de fama internacional, profundamente católico, y que, además, admiraba a Lorca? Si ante las primeras amenazas de la semana anterior, el poeta no había querido molestar al compositor, ¿no sería lógico ahora, ante la marcha de los acontecimientos, pedir asilo en su casa?”. GIBSON, Ian: Cuatro poetas en guerra, Barcelona, Planeta, 2007, pp. 198 y 202. Lamentablemente la indecisión de unos y otros no permitió verificar la bondad de aquella propuesta.

${ }^{59}$ MOLINA FAJARDO, Eduardo: Los últimos dias de García Lorca, Barcelona, Plaza y Janés, 1983 , pp. 93 y $157-165$.

${ }^{60}$ GARCÍA LORCA, Francisco: Federico y su mundo, Madrid, Alianza Tres, 1982, p. 153.

${ }^{61}$ En diciembre de 1928 García Lorca había publicado la primera parte de la "Oda al Santísimo Sacramento del Altar", que dedicó como homenaje a Manuel de Falla. Cuando éste la leyó, le escribió a Federico, el 9 de febrero de 1929, su desacuerdo con el tratamiento que el poeta había dado a un tema tan sublime para él: "A usted, que tan bien me conoce, no necesito decirle cuáles son las diferencias que nos separan ante el tema de su Oda. De ser tratado por mí lo haría con el espíritu puesto de rodillas, y aspirando a que toda la humanidad se divinizara por la virtud del Sacramento. Y con ello, la ofrenda: oro, incienso y mirra. Puros; sin mezclas... Usted me entienda, Federico, y perdóneme si en algo le molesto". En opinión de Gibson, la publicación de la Oda "no supuso el enfriamiento del sincero afecto sentido por Falla hacia Federico, aunque sí parece probable que la reacción adversa del compositor hizo que Lorca acudiera con menos frecuencia, a partir de entonces, al Carmen de la Antequeruela Alta". GIBSON, Ian: Federico García Lorca. 1. De Fuente Vaqueros a Nueva York, 1898-1929, Barcelona, Grijalbo, 1985, pp. 581-582. 
ron a ser simbólicos y los suministros estaban garantizados por la riqueza agrícola de la Vega, auténtica despensa en aquella España desabastecida.

Poco a poco Falla va sobreponiéndose a tanta catástrofe y va rompiendo su aislamiento para hablar con sus amigos de Granada ${ }^{62}$, recibir a Segismundo Romero que le viene a ver desde Sevilla e, incluso, al poeta “oficial" del régimen, José María Pemán, que acude a visitarle en Granada. Efectivamente, Pemán visitó a Manuel de Falla en su Carmen de la Antequeruela y el 28 de septiembre de 1937, realizó en el cercano Carmen de Santa Rita, propiedad de Ramón Pérez de Roda, una lectura del poema aún inédito La Bestia y el Ángel, en presencia de Manuel de Falla y de algunos miembros destacados de la sociedad granadina, o de la media sociedad granadina, como ha escrito Eduardo Quesada ${ }^{63}$, tales como Antonio Gallego Burín, Antonio Marín Ocete, Francisco Prieto Moreno, Alfonso García Valdecasas, José María Rodríguez-Acosta, Enrique Gómez Arboleya, Francisco García Carrillo o Valentín Ruiz Aznar, entre otros $^{64}$.

Ellos terminaron convenciéndole para realizar algunos gestos que él no tenía muy claro que debiera llevar a cabo, como su participación en el homenaje que en Granada se realizó al general Queipo de Llano. Falla se lo pensó, su firma no se incorporó finalmente al álbum de adhesiones, pero tampoco el compositor quería que su ausencia se interpretara como hostilidad "inmanifiesta", así que, finalmente, lo hizo de manera particular, mediante una carta en la que expresaba esa adhesión pretendida, pero supeditada a que "el divino Evangelio de justicia, de amor y de misericordia sea puesto en práctica", condición imprescindible para que España y su régimen obtengan la bendición de Dios. Algo que, en aquellos momentos, encerraba un mensaje más que suficiente. He aquí el texto íntegro de aquella misiva:

"Señor de toda mi consideración: Desde que me enteré del homenaje que le ofrecía Granada por la espléndida hazaña de julio con la que inició Vd. en España su movimiento salvador, hice el propósito de adherirme a él cumpliendo un deber ineludible para todo español que merezca serlo; pero hallándome enfermo, tuve que rogar a la bondad de algunos amigos que me informaran del texto dedicatoria del álbum de adhesiones, y ello ante el escrúpulo de que en su redacción pudiera mezclarse algún concepto de posible interpretación política, en cuyo caso, dado el voluntario apartamiento en que, durante toda mi vida, me he hallado de cuanto a política trascienda, lo hubiera hecho constar como complemento de mi adhesión. Ahora bien: inútil fue el empeño con que procuraron complacerme aquellos buenos amigos, y de este modo llegó el día en que supe, con gran disgusto mío, que era ya tarde para permitirme el honor de adherirme al homenaje. Por eso quiero ahora cumplir aquel deseo, rogando a Vd., Sr. General, acepte la expresión del mismo, que le dirijo con toda mi voluntad

${ }^{62}$ Francisco García Lorca escribió que "Mi familia contaba con agradecimiento las frecuentes visitas de don Manuel tras los asesinatos de mi hermano y mi cuñado. Las simples visitas a una familia marcada eran ya de agradecer en un vecindario aterrorizado". GARCIA LORCA, Francisco: Federico y su mundo..., pp. 153-154.

${ }^{63}$ QUESADA DORADOR, Eduardo: "Imágenes de Manuel de Falla en Granada", en Manuel de Falla en Granada, Granada, Publicaciones del Archivo Manuel de Falla, 2001, p. 149.

${ }^{64}$ Patria, Granada, 29-9-1937, p. 3. 
puesta en Dios y en España. Y a Dios le pido que el santo grito de "Viva Cristo Rey" que tantos mártires lanzan al morir, tenga fecunda eficacia en el convencimiento y en las obras de los cristianos españoles que aún vivimos. Esto es: que el divino Evangelio de justicia, de amor y de misericordia sea puesto en práctica. Solo así obtendremos la bendición de Dios que haga realmente eficaz para un porvenir próximo tanto sacrificio y tanto heroísmo como admiramos cada día" ${ }^{65}$.

Don Gonzalo se limitó a acusar recibo de aquella carta. Poco podía decir.

Las relaciones de Manuel de Falla con las autoridades locales y con el nuevo régimen se fueron normalizando y ante la inevitabilidad de los hechos se alegraba de cualquier acontecimiento que permitiera vislumbrar un final próximo de la guerra ${ }^{66}$. Incluso aceptó adaptar a marcha el "Himno de los Almogávares", de la obra Los Pirineos, de Felipe Pedrell, que le solicitó para las milicias juveniles el arquitecto y jefe local de Falange Francisco Prieto Moreno ${ }^{67}$. Según Fernando Sánchez, la petición la realizó a Falla el propio general Luís Orgaz quien, en una visita realizada a Granada como inspector de la región militar, se entrevistó con el compositor. La letra para aquel himno la facilitó José María Pemán y el encargo, siempre pendiente de revisiones posteriores, quedó culminado antes de finalizar aquel año de $1937^{68}$.

Pero una cosa era aceptar los hechos consumados y otra muy distinta que a Manuel de Falla le pasara desapercibido moralmente el pie que, bajo una fotografía suya y de Pemán insertaba $A B C$ de Sevilla el 7 de octubre de 1937, cuando les calificaba como "Poeta y músico de la Cruzada". Ante aquella información, el diario $A B C$, en su edición de Madrid, publicaba el día 15 un suelto de otro periódico catalán denominado El Diluvio que titulaba “¡Falla, con los facciosos!” en el que mostraba la extrañeza que le había producido "la noticia de que el maestro Falla estaba con los nacionales y hasta va a dedicar a nuestro Movimiento un poema musical en el que trabaja con toda la actividad que le permite su estado de salud" 69 . El periódico local de Granada, Ideal, comentaba aquella noticia afirmando que "No nos explicamos el asombro de El Diluvio. Creemos que el maestro Falla tiene bien probado su patriotismo para que se le pudiera ofender pensando que, en esta ocasión podría inclinarse del lado de los rojos. Hace mucho tiempo que rompió con ellos... ¿Cree El Diluvio que la religiosidad de don Manuel de Falla no es, como todo lo suyo, sincera, profunda y desinteresada? Si tan mal le conoce El Diluvio es el único que no le conoce en la zona roja"70. El malestar que aquello produjo al maestro Falla fue tal que se sintió

${ }^{65}$ AMF, carpeta 7459. Carta de Manuel de Falla a Gonzalo Queipo de Llano, 20-10-1936. Queipo le agradeció su adhesión en carta de 27-10-1937.

66 SÁNCHEZ GARCÍA, Fernando: La correspondencia inédita entre Falla y Pemán, Sevilla, Ediciones Alfar, 1991, pp. 66 y 117.

${ }^{67}$ OROZCO DÍAZ, Manuel: Falla: biografía ilustrada, Barcelona, Destino, 1968, p. 175. Pahissa afirma que la adaptación de la obra de Pedrell se realizó a petición de un cuerpo de voluntarios que se titulaban los "patriotas" que "no lo utilizaron porque no respondía a los deseos ni al gusto de aquella gente”. PAHISSA, Jaime: Vida y obra de Manuel de Falla, Buenos Aires, Ricordi, 1956, p. 178 (1ª edición 1947).

${ }^{68}$ SÁNCHEZ GARCÍA, F.: La correspondencia inédita..., pp. 33-40.

${ }^{69} A B C$, Madrid, 15-10-1937, p. 4.

${ }^{70}$ Ideal, Granada, 2-11-1937, p. 3. Copia de la carta en AMF, Carta al Director de Ideal, 4-11-1937. 
obligado a replicar a dicha información y como no podía hacerlo desde la perspectiva de la religiosidad -"Es ciertísimo que, antes como ahora, Dios ha estado y está para mí sobre todas las cosas"-lo hizo desde la dedicación, negando discretamente estar trabajando en ninguna obra de loor a la Cruzada ${ }^{71}$ :

"La inexactitud que me veo obligado a rectificar, dadas las graves confusiones que pudiera producir en mi relación con las entidades que esperan la terminación de $L a$ Atlántida para su estreno, es esa laboriosa actividad que ustedes me atribuyen en la composición de una nueva obra. Desgraciadamente, y desde hace bastante tiempo, estoy imposibilitado de reanudar el trabajo que me ha ocupado durante estos últimos años, y que no es otro que la adaptación musical de ese poema de Verdaguer. Por consiguiente, si, como espero, la Providencia me permite reanudar la actividad de mi oficio, deberé consagrarla enteramente a la terminación de esa obra, con la cual aspira mi buena voluntad rendir homenaje a Dios y a nuestra Patria" 72 .

Como contrapartida de todo aquello, digamos que Manuel de Falla intervino para resolver algunas situaciones difíciles y que, entre otros logros, consiguió a través de la mediación de Pemán la liberación de su amigo y colaborador en tantos proyectos, el pintor y grabador Hermenegildo Lanz que, por cierto, había firmado con él aquel telegrama dirigido en 1931 a Alcalá Zamora como repulsa a los ataques a dependencias eclesiásticas ${ }^{73}$. No fue la única intervención, como se deduce de esta carta a Pemán, realmente elocuente de lo que pensaba Falla en aquellos momentos:

"Ahora, nuevas amarguras perturban mi espíritu: quiero referirme a la aplicación frecuente de la pena capital a personas cuyos delitos acusa, al menos en apariencia, notable desproporción.

Usted, sin duda, comparte estos sentimientos, pues todos sabemos sus altas convicciones religiosas y la nobleza de su corazón, y por eso me decido a escribirle confiando en que usted, con todo su prestigio, pueda influir eficazmente para que se limiten los hechos en cuestión.

Ya sé que en estos momentos, siendo tantos y tan horrendos los crímenes que determinaron el actual movimiento salvador de España, la serenidad de juicio se hace a veces dificilísima; pero por eso mismo creo de obligación estricta para los cristianos que insinuemos nuestros temores y nuestras amarguras a quienes, por el cúmulo de graves responsabilidades y preocupaciones, se ven a veces fatalmente obligados a recurrir a procedimientos expeditivos que en tiempos normales no pondrían seguramente en práctica. Y eso sin contar con que la voluntad de los mandos anteriores pudiera no ser siempre exactamente interpretada" ${ }^{\prime 74}$.

${ }^{71}$ "Me decía mi hermana Concha que, antes de abandonar Granada, quisieron las llamadas autoridades granadinas hacerle objeto de un homenaje, que don Manuel rechazó en una carta que, según mi hermana, mereció ser publicada en lugar recatado, medio oculta entre los anuncios de un periódico de la ciudad", GARCÍA LORCA, F.: Federico y su mundo..., p. 154.

${ }^{72}$ Ideal, Granada, 5-11-1937, p. 2.

${ }^{73}$ SÁNCHEZ GARCÍA, F.: La Correspondencia inédita..., pp. 72-74.

${ }^{74}$ Ibídem, p. 65. Carta de Falla a Pemán, 18-9-1936. 
Pemán le contestó a los pocos días en el sentido de que compartía sus preocupaciones:

"Su carta me llega como anillo al dedo, cuando yo precisamente estoy lleno de las mismas inquietudes que Vd. y he iniciado ya algunos pasos en este sentido, que Dios ha querido que tengan éxito en algunos casos particulares"75.

El 1 de enero de 1938 Manuel de Falla fue designado presidente del Instituto de España $^{76}$, organismo que aglutinaba a los miembros numerarios de las Reales Academias de la Lengua, de la Historia, de Ciencias Exactas, Físicas y Naturales, de Ciencias Morales y Políticas, de Bellas Artes ${ }^{77}$ y de Medicina. Pero Falla, que seguramente no había sido consultado para ello, no asistió a la prevista toma de posesión de aquel cargo el 6 de enero de 1938 en Salamanca, pretextando su quebrantada salud $^{78}$. Más aun, Falla manifestaría al Gobierno su imposibilidad para el desempeño de esta obligación y le rogó encarecidamente a Pemán, seguramente el inductor del nombramiento, su intervención para eximirlo de aquella responsabilidad; al final, una orden del Ministerio de Educación Nacional de 18 de junio de 1938, que deseaba a toda costa mantener a Falla en su nómina de cargos, otorgaba sus atribuciones al vicepresidente del Instituto, "hasta tanto que, restablecido de su salud, estime conveniente volver al ejercicio de su función"

Pese a tantas aproximaciones intentadas, no tuvo con él el régimen sensibilidad suficiente para evitar someterlo a la humillación de una depuración política, generalizada al terminar la Guerra Civil. El 6 de julio de 1939 el delegado de la Sociedad de Autores en Granada envió a Falla el cuestionario de depuración que debía remitir en 15 días a su central de Madrid, junto con dos avales firmados por dos personas de indudable afecto al nuevo régimen. Falla lo hizo y aunque no consta quién lo avaló, el 14 de agosto el Delegado General de la SGAE, José María Caruncho Astray emitió certificación en el sentido de "Que con fecha 10 de agosto de 1939 y en o que respecta a su actuación como autor de esta entidad, ha sido depurado favorablemente, por el Juez Militar nombrado al efecto, D. Manuel de Falla Matheu" ${ }^{80}$. Es una prueba de que nadie podía escapar al control político de las nuevas autoridades del régimen.

El día 1 de abril de 1939 terminó, pues, la Guerra Civil y Falla, que había tenido que renunciar a los numerosos reclamos que le llegaban para asistir al estreno de sus obras en Europa y cuya situación económica comenzaba a deteriorarse, recibió por aquellos días una invitación de la Institución Cultural Española de Buenos Aires, que

\footnotetext{
${ }^{75}$ Ibidem, p. 66. Carta de Pemán a Falla, 28-9-1936.

${ }^{76}$ Boletín Oficial del Estado, Madrid, 1-1-1938, pp. 5.074-5.

${ }^{77}$ El 13 de mayo de 1929 había sido elegido Académico de la Real de Bellas Artes de San Fernando, cargo a cuyo nombramiento se opuso, del que no llegaría a tomar posesión y del que se aceptaría su renuncia el 18 de marzo de 1935.

${ }^{78}$ PAHISSA, J.: Vida y obra de..., p. 203.

${ }^{79}$ Orden de 18 de junio de 1938. PASCUAL RECUERO, P.: Cartas a Segismundo Romero, p. 111 y SÁNCHEZ GARCÍA, F.: Epistolario inédito..., p. 48.

${ }^{80}$ AMF, carpeta 9.152
} 
celebraba ese año sus bodas de plata, para que el músico dirigiera en el teatro Colón de Buenos Aires unos conciertos con ese motivo.

Sus amigos de Granada le animaban a aceptar la invitación argentina, sus médicos lo alentaban, él parecía estar bastante decidido y, finalmente, el estallido, de la Segunda Guerra Mundial el 2 de septiembre, hizo que desaparecieran sus últimos recelos y que, sobreponiéndose al terror de un viaje tan largo, aceptara la invitación para trasladarse a un país que se había declarado neutral en el nuevo conflicto mundial. Juan Viniegra, que le visitó por entontes en la Huerta Grande de La Zubia, ha escrito que Falla le dijo: "Me voy a la Argentina. Me han propuesto unos contratos muy ventajosos. Mis ingresos están muy mermados con motivo de la Guerra Mundial, y aprovecho esta feliz ocasión para enmendar algo mi situación económica actual"»1.

Efectivamente, la situación económica de Manuel de Falla en ese momento era tan mala como lo había sido en sus años de escasez en París y en Madrid. A mediados de septiembre de 1939 el saldo de su cuenta corriente en la banca RodríguezAcosta de Granada ascendía a 3.408 pesetas (4.900 euros en valor constante a enero de 2.011). Los ingresos por derechos de autor eran escasísimos y estaban bloqueados, primero por la guerra de España, ahora por la guerra Mundial y Manuel de Falla y su hermana María del Carmen, siempre extraordinariamente parcos en el gastar, habían tenido que reducir su consumo a niveles realmente mínimos. Tenía Falla también una pequeña cartera de valores compuesta por cédulas hipotecarias y deuda pública cuyo valor de compra ascendía a 76.881 pesetas pero que el cierre de la Bolsa las hacía invendibles. Lo que les quedaba en efectivo apenas daba para tirar unos cuantos meses más y es en ese contexto en el que Manuel de Falla tomó la tremenda decisión de viajar a Argentina donde por la dirección de cuatro conciertos en el Teatro Colón de Buenos Aires ofrecieron al compositor unos honorarios de 21.700 pesos, equivalentes a 61.411 pesetas (88.500 euros en valores constantes a enero de 2011)

Y, en fin, Falla y su hermana María del Carmen, huyendo de otra guerra que no creían poder soportar, con tres mil pesetas en el bolsillo que constituían prácticamente todo su capital (4.300 euros actuales), abandonaron Granada el 28 de septiembre por ferrocarril, camino de Barcelona, donde el 2 de octubre embarcaron en el "Neptunia" que les dejó en Buenos Aires el 18 del mismo mes. "Llegaba [escribió Pedro Massa] en un estado físico realmente impresionante: consumido, pálido, hecho una pavesa. No tenía más que ojos y aquella sonrisa ancha y dulce, que era como la flor de su simpatía" 82 . El caso es que lo que en principio era una estancia temporal para recomponer su maltrecha economía, se convirtió en una permanencia de más de siete años, a la que solo su fallecimiento puso desgraciado término.

Falla llegó a Argentina en un momento políticamente convulso. Eran los momentos finales de la corta presidencia de Roberto Ortiz, cuya prematura muerte y los procesos conspiratorios que a lo largo de toda ella se produjeron, llevaron a la máxima magistratura del país, sucesivamente, a Ramón Castillo, Pedro Ramírez, Edelmiro

${ }^{81}$ VINIEGRA Y LASSO DE LA VEGA, Juan J.: Vida íntima de Manuel de Falla y Matheu, Cádiz, Diputación Provincial y otras instituciones, 1966, p. 203.

${ }^{82}$ MASSA, Pedro, "Manuel de Falla en la Argentina", Buenos Aires, La Prensa, citado en Poesía. Revista ilustrada de información poética (1991) p. 242. 
Farell y, finalmente, Juan Domingo Perón, un periodo que, con sus prolegómenos, ha sido calificado por un historiador como "la era infame" en la historia de Argentina ${ }^{83}$. Desde luego, si alguien piensa que Manuel de Falla encontró en Argentina un clima político respetuoso con las libertades, formalmente democrático y con un claro compromiso social, distinto de aquel que dejaba en Europa, habrá que pedirle una lectura más atenta de la historia argentina del periodo. Ciertamente que Falla evitó volver a verse sumido en una situación de guerra, que tanto le horrorizaba, pero una cosa era la cuestión bélica y otra muy distinta la situación política que, en Argentina, resultaba estar tan dañada como en Europa desde el punto de vista de lo que era la libertad como objetivo y la democracia como método. Y una observación más: probablemente, la sociedad argentina con la que Falla se relacionó, rica, culta, burguesa, abierta, generosa y europeizada, no se correspondía exactamente con el perfil general de los quince millones y medio de personas que entonces habitaban el país.

Así que Falla decidió pasar de puntillas sobre la política local y ponerse a salvo de los horrores de la guerra en Europa que es lo que le torturaba y, de paso, rodearse de una coraza para resistir las ofertas de regreso con las que el Gobierno español le iba a empezar a tentar antes, incluso, de su llegada a Buenos Aires.

\section{La tentación de la Patria}

Efectivamente, cuando el "Neptunia" hizo escala en Río de Janeiro en la ruta que llevaba a Manuel de Falla y a su hermana a Buenos Aires, el compositor recibió un telegrama del Gobierno español, deseoso por razones obvias de forzar un inminente regreso del compositor, en el que se le comunicaba que en España le había sido concedida de manera vitalicia una pensión anual de 25.000 pesetas (36.000 euros en valores constantes a enero de 2011), "pagaderas a partir de su regreso a la patria". Al llegar a Buenos Aires Falla escribió al ministro de Educación, Ibáñez Martín, acerca de la pensión concedida y de su regreso a España, agradeciéndole tan generosa iniciativa:
"Ahora bien dada la situación económica actual de nuestra patria como consecuencia de la guerra que acaba de liberarla, y dado también la evidente mejoría con que, gra- cias a Dios, mi curación se va afirmando y que me permite reanudar con toda eficacia mis trabajos, créome en el deber de rogarle que aplace el cumplimiento de tan gene- roso auxilio acordado para mi regreso a España, no sólo hasta entonces, sino hasta el momento, que espero en Dios sea lejos, en que por falta de salud pudiera volver a interrumpir el ejercicio eficaz de mi profesión y a faltarme, como fatal consecuencia, los medios de vida que ella me proporciona" ${ }^{44}$.

${ }^{83}$ TELLO, Antonio: Historia breve de Argentina. Claves de una impotencia, Madrid, Silex, 2006, p. 139

${ }^{84}$ AMF, carpeta 7116. Carta de Manuel de Falla, 14-11-1939. DE PERSIA, J.: Los últimos años de..., p. 68. En la carta recomienda a su hermano Germán para cualquier actividad profesional de servicio a España. La carta termina con la expresión de su gratitud personal y su "adhesión a S.E. el Generalísimo". 
Dignidad y fe prudente en sus propias posibilidades no son virtudes de las que Manuel de Falla anduviera escaso.

Afortunadamente, Falla no lo necesitó. Los honorarios de los cuatro conciertos del teatro Colón en noviembre de 1939, los de otros dos celebrados en Radio El Mundo de Buenos Aires en diciembre de 1940, dos más en el mismo lugar en diciembre de 1942 y los pagos que en los años finales de su estancia argentina y de su propia vida comenzaron a llegar por la utilización de su música en diversas películas en Estados Unidos, fueron suficientes para que él y su hermana vivieran con el nivel que ellos requerían que era, por otra parte, bastante elemental y muy poco exigente.

No pudo conseguir de la Sociedad de Autores Españoles, pese a sus reiterados intentos, que el importe de sus derechos de autor recaudados y retenidos en España se le enviaran a Argentina. A comienzos del verano de 1940 el compositor se dirigió al Secretario General de la Sociedad en Madrid consultándole tal posibilidad; Joaquín Guichot le respondió negativamente: "es de todo punto imposible acceder a sus deseos porque el Instituto Español de Moneda Extranjera no autoriza el pago de los derechos de España por compensación, pues ello supone un empleo de divisas que el Gobierno quiere reservar para las necesidades del país"85. Y ante una nueva petición de Falla, le confirmaron la misma situación tres meses después ${ }^{86}$. Seguramente el Gobierno intentaba mantener esta carta en la manga para jugarla como más conviniera a sus intereses. Las circunstancias de la posguerra se hacían notar también en la distancia.

En un momento de necesidad para Falla y gracias a las gestiones del músico exiliado catalán Jaime Pahissa con José Ignacio Ramos, delegado de la Sociedad de Autores Españoles en Argentina, se consiguió que Eduardo Marquina, presidente entonces de dicha Sociedad, autorizara a Ramos a pasar a Falla "sin tasa ni compromiso alguno, la cantidad que precisara para poder vivir con holguras". Dicha cantidad fue finalmente de mil pesos, que se computarían a cuenta de sus derechos de autor, congelados en París, en Londres y también en España ${ }^{87}$. Cuenta Pahissa que al cabo de un par de meses de usar de este dinero, Falla recibió algunos dólares por la autorización de utilizar La Danza del fuego en una película en la que aparecía Rubinstein y renunció a la "pensión" que la Sociedad de Autores le enviaba desde España ${ }^{88}$. En la carta que el propio Falla escribió a Marquina le indicaba, con su sincero agradecimiento, "Mi deseo (como ya Vd. sabe) es el de reservar en lo posible el importe de mis derechos de autor para cuando regrese a España, y tanto más cuanto que, resuelto por ahora el problema (gracias a unos derechos de filmación que recibí de Estados Unidos y a otros nuevos que espero recibir), mi situación económica parece quedar

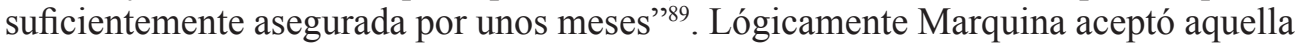

\footnotetext{
${ }^{85}$ AMF, carpeta 9.152. Carta de Joaquín Guichot, 9-7-1940.

${ }^{86}$ AMF, carpeta 9.152. Carta de la SGAE, 16-10-1940.

${ }^{87}$ CASANOVAS, José: Manuel de Falla, cien años, Barcelona, Ediciones de Nuevo Arte Thor, 1976, p. 62.

${ }^{88}$ PAHISSA, J.: Vida y obra de..., pp. 200-201.

${ }^{89}$ AMF, carpeta 9.153. Carta a Eduardo Marquina, 6-10-1944.
} 
decisión pero fue muy explícito con el delegado de la Sociedad de Autores en Argentina, en el sentido de que se desviviera porque a don Manuel no le faltara nada:

"Mientras esté en esa -le ordenaba- y aunque de momento no ha aceptado más que la primera entrega de la asignación fijada por esta Sociedad al mismo, es necesario que estés atento a las necesidades del señor Falla, con el fin de que, utilizando la autorización que se te dio de entregar al mismo mil pesos mensuales, puedas atender debidamente la situación económica del ilustre compositor. Nuestro deseo es que no le falte nada y que tenga la grata satisfacción de saber que sus compañeros los autores españoles no le olvidan y anhelan que pronto esté entre ellos"90.

A comienzos de 1943 el ingeniero José Manuel Hernández Suárez, amigo de Falla y Director de la Institución Cultural Española que había organizado el viaje de don Manuel a Argentina, hizo un viaje a España. Falla le hizo varios encargos que el ingeniero realizó con mayor o menor éxito, sobre todo el de clarificar sus cuentas con la Sociedad General de Autores Españoles. En la carta en que le daba cuenta de ello le transmitía también una opinión muy favorable sobre la situación española cuando le decía:

"En Madrid todos se acuerdan de Vd. con respeto y cariño y desearían tenerle otra vez en España, tanto el mundo oficial (incluso el mismo ministro Ibáñez Martín que se interesó mucho por saber de Vd.) como todos sus amigos de la Sociedad de Autores, los Fernández Shaw y, por último, Don Pedro Borrajo y sus compañeros de Granada, con quienes hablé por teléfono. He de decirle que las circunstancias morales y materiales de la vida española están sufriendo una modificación profunda que en estos últimos meses se ha acelerado en el buen sentido. Tan es así que, en contra a lo que aquí se cree, la gente allí está más llena de optimismo y de vida que en estas tierras y, salvo núcleos reducidos, encaran las cosas con una buena voluntad y con un deseo de ayuda mutua para salir del paso que aquí escasea"91.

Un año después, el mismo José Manuel Hernández Suárez le manifestaba su preocupación, un tanto enigmática pero menos optimista, ante el previsible final de la Segunda Guerra Mundial:

"las consecuencias del fin de las hostilidades son muy de temer, no solamente en España, sino en todo el mundo, incluso aquí mismo. Justo es que confesemos que las últimas medidas que se están tomando, muchas de las cuales atacan esencialmente la estructura económica y social del país, no presagian nada bueno. Pero, ¿se seguirá por este camino? ¿El país tendrá vitalidad para evitarlo y enderezar el rumbo? Nada es eterno en este mundo, pero no puede construirse tampoco nada firme sobre nubes ${ }^{992}$.

${ }^{90}$ AMF, carpeta 9.153. Traslado de la carta que realiza a Manuel de Falla José Ignacio Ramos, 24-2-1945.

${ }^{91}$ AMF, carpeta 7.105. Carta de Hernández Suárez, 18-5-1943.

92 AMF, carpeta 7.106. Carta de Hernández Suárez, 10-5-1944. 
Dos años después, en septiembre de 1946, le escribía desde Canarias, en un nuevo viaje que realizó a España: "De las cosas aquí solo le diré que se parecen como una gota de agua a otra a las de ahí, con la única salvedad de que el espíritu cuenta aquí algo más" ${ }^{\prime 93}$. No es de extrañar este comentario si se tiene en cuenta que desde el mes de febrero de aquel año de Argentina se había adueñado un régimen con ciertas similitudes con el español y bastantes simpatías mutuas: el peronismo.

Desde 1944 el Gobierno intensificó su esfuerzo por conseguir el regreso de Manuel de Falla a España ${ }^{94}$. Aparte de las razones culturales y humanitarias que hubiera en ello, la baza política era fundamental para el régimen en aquellos momentos de aislamiento internacional, que no haría más que empeorar a partir de la terminación de la Guerra Mundial.

Ya vimos cómo en 1939, cuando el compositor había iniciado su viaje a Argentina, el Gobierno le tentó con una suculenta pensión con la condición de que regresara al país y cómo Falla pidió al ministro el aplazamiento de aquella "generosa iniciativa" 95 . El 2 de abril de 1940 el ministro de Educación Nacional, Ibáñez Martín, le hizo llegar su nombramiento como presidente honorario del Patronato "Marcelino Menéndez y Pelayo" del Consejo Superior de Investigaciones Científicas ${ }^{96}$. No consta que Falla rechazara aquel nombramiento, aunque ciertamente no llegó a ejercerlo. Sin embargo, sí aceptó la Gran Cruz de Alfonso X el Sabio que el 13 de julio de 1940 le otorgó el general Franco, a propuesta del ministro de Educación Nacional y con la deliberación del Consejo de Ministros. La respuesta, manuscrita y mecanografiada que existe en el Archivo del compositor, deja entrever la ambigüedad con la que, en algunos aspectos relacionados con la política española, se movió Manuel de Falla, cuando le escribió al ministro:

"Considero tan grande como inmerecido el honor que con tal merced recibo y que profundamente agradezco, y ruego a V.E. transmita estos sentimientos a Su Excelencia con mi reiterada y muy respetuosa adhesión. Reciba Vd. también Sr. ministro la expresión de mi más sincera gratitud por su propuesta, gratitud que hago extensiva al Consejo deliberante" ${ }^{97}$.

Aquella relación que le facilitaron los contactos ministeriales, no tardó Manuel de Falla en aprovecharla para interceder a favor de sus amigos, como lo había hecho en Granada. Así, en una carta que Manuel de Falla escribió a Ibáñez Martín el 8 de enero de 1941 le pedía su mediación para salvar la vida de Miguel Salazar, seguramente hermano de su gran amigo el musicólogo Adolfo Salazar, exiliado a México al estallar la Guerra Civil y de Cipriano de Rivas Cherif, escritor y periodista cuñado de Manuel Azaña con quien Manuel de Falla había tenido una discreta relación ${ }^{98}$ :

\footnotetext{
${ }^{93}$ AMF, carpeta 7.106. Carta de Hernández Suárez, 9-9-1946.

${ }^{94}$ Poesía. Revista ilustrada de información poética (1991) p. 239.

${ }^{95}$ DE PERSIA, J.: Los últimos años de..., p. 165.

${ }^{96}$ AMF, carpeta 7.116. Oficio del ministro de Educación Nacional de 2-4-1940.

${ }_{97}$ AMF, carpeta 7.116. Comunicación del Subsecretario del Ministerio de Educación Nacional, 30-7-1940. Borrador manuscrito y copia mecanografiada de la carta de Falla al ministro, 25-8-1940.

${ }^{98}$ AMF, carpeta 7497. Correspondencia entre Manuel de Falla y Cipriano de Rivas Cherif.
} 
"Y ahora, Sr. ministro, voy a permitirme hablarle de algo que en estos últimos meses me está haciendo pasar momentos amargos y llenos de inquietud. Se trata de Miguel Salazar, a quien me une vieja y fiel amistad, cimentada en nuestra colaboración en cosas musicales y especialmente desde la fundación en Madrid de la Sociedad Nacional de Música y de la Orquesta Filarmónica. Tanto nuestro Cónsul Gral. Como nuestro Embajador me dicen que no creen haya que temer nada irremediable, pero es lo cierto que dado que se publicó en la prensa de aquí, hace más de dos meses, un telegrama de España acogiendo rumores de que a Miguel Salazar, Rivas Cherif (para quien también suplico toda la posible indulgencia) se les conmutaba la pena capital por otra temporal, no ha llegado ninguna confirmación oficial de esos rumores tranquilizadores. En fin, en las buenas manos de Vd. pongo este triste asunto, y ojala pueda darme las tan deseadas noticias. Además, y como ya he pedido al Sr. Embajador, yo ruego que mi nombre vaya unido a toda petición de indulto. Si viera Vd., Sr. ministro, cuánto ganaría en estos países el prestigio de España con la confirmación oficial de ese y de otros rumores relativos a indultos o a conmutación de penas! Creyendo cumplir un deber me permito decírselo, pues el silencio oficial en esos casos es aprovechado por muchos para hacer propagandas más que lamentables" $"$.

No parece que aquellas peticiones sensibilizaran mucho a las autoridades españolas en el sentido que el músico les proponía.

Poco a poco y a medida que se iban desarrollando los acontecimientos Falla fue adoptando una postura más precavida sobre sus relaciones con el Gobierno de España y ello a pesar de la subliminal campaña envolvente que se desarrollaba desde la Sociedad de Autores, que tenía el mismo objetivo del Gobierno, el regreso de Falla, cuyo delegado en Argentina desde comienzos de 1944, José Ignacio Ramos era, a la vez, agregado de prensa de la embajada española en Buenos Aires y quien, poco a poco, se fue introduciendo en temas que poco tenían que ver con los derechos de autor.

"Estos días [le escribe en diciembre de 1944] habrá observado Vd. una persistente campaña sobre la supuesta dimisión del general Franco. Puedo asegurarle que diariamente llega hasta nuestro poder un noticiario que sobre España recibe la United Press, y es curioso observar a través de estas noticias, que ningún diario de aquí recoge, el desarrollo de la vida normal en España: conciertos, exposiciones, conferencias, actos oficiales, notas anecdóticas, etc., etc., que reflejan que el desarrollo de la vida en España es absolutamente normal, impresión que reflejan igualmente todos los que de allí llegan en avión, que son varias personas mensualmente" ${ }^{100}$.

Y como en el caso de Hernández Suárez, desde Argentina, incluso por personas simpatizantes o colaboradores con el régimen, se perciben a la terminación de la Segunda Guerra Mundial unas perspectivas de cambio que tardarían mucho tiempo en producirse:

99 AMF, carpeta 7.116. Borrador manuscrito de la carta de Manuel de Falla al ministro de Educación Nacional, 8-1-1941.

${ }^{100}$ AMF, carpeta 9.153. Carta de José Ignacio Ramos, 11-12-1944. 
"Las noticias que llegan de España son muy buenas, [le escribe José Ignacio Ramos] excelentes, en contraste con la propaganda desatada en la prensa y que a usted no le escapará en el grado que es tendenciosa. Parece que se va a una evolución rápida del régimen, pero pacífica y ordenadamente, sin que para nada influya en ella la actitud política de algunos grupos, aunque sí las nuevas orientaciones del mundo. La situación alimenticia y económica concuerdan testigos fidedignos que es francamente buena, en contra de lo que últimamente se afirma aquí" ${ }^{101}$.

En 1945 el embajador español le escribió comunicándole que había sido designado por el Gobierno consejero de honor del Consejo Superior de Investigaciones Científicas, aunque él, muy precavido le respondió de manera muy distinta a como lo había hecho en circunstancias parecidas cinco años antes, en un documento que es el que mejor refleja la posición del compositor:

"Soy y he sido siempre fiel súbdito de España, y con mi trabajo he procurado servir a mi patria dentro de mis posibilidades, pero permaneciendo siempre alejado de todo cuanto pueda tener carácter político, y en ese alejamiento quiero seguir viviendo hasta que Dios disponga de mí. Ya sé que el muy agradecido nombramiento de que tratamos, además de su significado honorífico, se refiere a un Consejo de Investigaciones Científicas, y por lo tanto ajeno a toda política; pero dado el carácter oficial del organismo, bien pudiera ocurrir en ocasiones que, con el mejor propósito y obedeciendo a especiales circunstancias, se creyera en el deber de manifestarse corporativamente en un sentido que, más o menos acusara una tendencia política, cuya aparente adhesión por mi parte contrariase los firmes propósitos que me he permitido manifestarle a usted" 102 .

Si Falla, en algún momento, dejaba ver alguna remota posibilidad de regreso, Ramos se aferraba a ella con esperanzada ilusión. En marzo de 1945 Falla le envió su saludo afectuoso para Eduardo Marquina por la generosidad que desde la Sociedad de Autores habían tenido con él:

"Envío a todos mi más cordial saludo deseando vivamente hallarme de nuevo entre tan buenos amigos y compañeros, y este deseo de regresar a la patria ha sido, como Vd. sabe, una de las principales razones por las que deseo reservar, en cuanto me sea posible, los derechos que la Sociedad me administra"103.

Ramos se ilusiona. Habla con Lojendio, embajador en Uruguay. Éste con Lequerica, ministro de Asuntos Exteriores y en nombre del mismo y del Gobierno le transmite "que si algún día piensa regresar a España tendrá usted las mayores facilidades, lo mismo si desea reservar pasaje en avión que cualquier otra cosa que precise y me añadió que, a raíz de una crónica que yo escribí relatando su visita y su deseo de algún día residir en el pueblo de Huerta Chica, el Gobierno acordó comprarle allá la

\footnotetext{
${ }^{101}$ AMF, carpeta 9.153. Carta de José Ignacio Ramos, 24-9-1945.

102 DE PERSIA, J.: Los últimos años de..., p. 165.

103 AMF, carpeta 9.153. Carta a José Ignacio Ramos, 16-3-1945.
} 
casa que usted elija y hasta no sé si le entendí al señor Lojendio que tenía ya una casa comprada". Y como sabe cómo se las gasta Falla en relación con el asunto político le aborda por otro flanco: "Supongo que esta noticia ha de agradarle a usted, pues al margen y por encima de toda política, este hecho demuestra la simpatía y el gran recuerdo que de Vd. se conserva en España"104.

En 1946 la propuesta fue mucho más directa y se la transmitió otro extraño exiliado, su vecino y amigo Francesc Cambó, el 6 de julio por encargo del embajador español en Buenos Aires, el conde de Bulnes:

"El Gobierno español tiene gran interés en que vaya usted a España, no para una visita, sino para quedarse a residir allí, y le ofrece todo lo que usted quiera: gastos de viaje, casa confortable en España, una pensión y cuanto usted necesite para vivir en paz y poder trabajar a sus anchas. Y aquí ha terminado mi misión; usted resolverá como le parezca, que será siempre lo mejor [le dice Cambó, poco convencido del encargo que cumple; pero como viejo lobo de la política le añade] naturalmente que si usted se decidiera a aceptar, convendría precisar mucho las cosas para evitar que después de haber dejado este rincón en que no lo pasa usted del todo mal, no se encontrara en España con dificultades y molestias por no haber puesto muy en claro las cosas"105.

Lo verdaderamente curioso es que esta propuesta se hiciera por escrito, cuando era una cuestión que exigía por su propia naturaleza un tratamiento discreto y ambos residían en Alta Gracia, apenas a quinientos metros de distancia.

Pero don Manuel lo tenía claro, cuando sin cerrar el camino a la posibilidad del regreso le respondía:

"Aunque tan honrado como agradecido por sus ofrecimientos en nombre del Gobierno, sigo pensando como hasta ahora he pensado en cuanto se relaciona con mi regreso a España, o sea que por la tranquilidad que exigen el delicado estado de mi salud y la posible eficacia de mis trabajos de música, debo esperar, para mi tan deseado regreso a nuestra patria, a que en Europa comiencen siquiera a estabilizarse las cosas"106.

Realmente Falla era completamente pesimista respecto de que pudiera producirse algún día aquella estabilización europea de la que hablaba. "Ahora [escribe el 5 de enero de 1946 a las hermanas Maruja e Isabel Luzuriaga] parece que pesa sobre el mundo tan inmenso misterio que a veces llega hasta hacernos temer que estamos muy próximos al fin de la segunda generación (la postdiluviana), porque la humanidad se destruirá a sí misma"107.

En aquella situación, Manuel de Falla dejaba ver a través de uno de sus donativos una cierta simpatía con el compromiso político, con el que siempre fue la discreción personalizada. Es lo que sucede con las dos entregas de cincuenta pesos cada una que

${ }^{104}$ AMF, carpeta 9.153. Carta de José Ignacio Ramos, 5-7-1945.

${ }^{105}$ Carta de Francisco Cambó desde el Sierras Hotel, de Alta Gracia, el 6 de julio de 1946. DE PERSIA, J.: Los últimos años de..., p. 198.

${ }^{106}$ Carta a Francisco Cambó, 9-7-1946.

${ }^{107}$ DE PERSIA, J.: Los últimos años de..., p. 198. 
Manuel de Falla realizó a María Luisa Navarro de Luzuriaga, madre de las hermanas antes citadas. Era ésta la esposa de Lorenzo Luzuriaga, pedagogo institucionista exiliado en Argentina, que presidía el "Club femenino pro ayuda al español demócrata exiliado". A través del mismo había conseguido enviar en septiembre de 1945 veinte toneladas de alimentos, ropas y medicinas a Francia, para atender a los antiguos presos de los campos de concentración y a los españoles residentes en Francia. Ahora recolectaba ayudas para los niños españoles y para el hospital español de Toulouse ${ }^{108}$. Falla le hizo llegar un cheque de 50 pesos el 19 de enero de 1946 y le anunciaba que, en cuanto le fuera posible, le realizaría un nuevo envío ${ }^{109}$, algo que ocurrió, con la misma cantidad, el 9 de agosto.

Miedo, por consiguiente, a la guerra en Europa, pero miedo también a la utilización que de su regreso pudiera hacerse como compromiso político del que, como se ve, se fue lenta pero progresivamente distanciando.

Lo cierto es que el Gobierno español nunca le perdió la pista ni desistió de conseguir que, algún día, Manuel de Falla regresara a su país. Le tentó con prebendas, distinciones, honores y dinero y consiguió que algunos de sus amigos y colaboradores, José Ignacio Ramos o Juan Manuel Hernández Suárez, trabajaran arduamente para esta causa.

De Hernández Suárez es este informe dirigido al embajador de España que por las referencias que en el propio documento figuran no fue el único emitido y que demuestra y conocimiento muy profundo de los problemas del compositor, que fue elaborado en una fecha no precisada de 1945 y que contiene tanto información sobre Falla como propuestas para conseguir los objetivos del Gobierno:

"Sigue en su casa de Alta Gracia (nota del 8 de julio de 1944) con grandes deseos de volver a España y al mismo tiempo con un enorme temor de dar ese paso. Situación de ánimo fácil de comprender para quien conoce su estado de salud y su ánimo.

Físicamente ha mejorado; no ha tenido en el último año ningún achaque serio; ha aumentado un poco de peso. De todos modos su salud es siempre precaria y no es posible pensar en someterla a un esfuerzo serio. Así que no podría de ningún modo ir a España, sino en un viaje cómodo y directo que no durase más que 15 a 16 días.

Su ánimo está siempre muy inquieto y a ello contribuye no poco el aislamiento en que vive y las informaciones contradictorias que le dan sus visitas, lo que unido a la penosa impresión que le produce la lectura de la prensa, sobre todo de la española, hace que nos haya confesado que a veces tiene la impresión de "sobrevivirse a sí mismo". Tiene el firmísimo propósito de conservar su independencia moral y material y caso de volver a España de continuar alejado de las grandes ciudades.

No desea volver a Granada que tiene para él tristes recuerdos. Su ideal sería ir a las sierras de Córdoba y en ella a la propiedad llamada "Huerta Chica" lindera con la finca "Los Arcos" del Marqués de la Vega Armijo. Si no estamos mal informados Huerta Chica es propiedad de la familia Vallejo algunos de cuyos miembros residen actualmente en Buenos Aires.

${ }^{108}$ DE PERSIA, J.: Los últimos años de..., pp. 88-89.

${ }^{109}$ Carta de Manuel de Falla, 25-1-1946. DE PERSIA, J.: Los últimos años de..., p. 89. 
Contribuiría también poderosamente a su vuelta a España su deseo de estrenar en Barcelona "La Atlántida" a cuyo fin una invitación directa del Ayuntamiento y Círculos musicales de aquella ciudad que le detallasen un poco las facilidades que puedan prestarle sobre todo en lo que concierne a los coros del "Orfeó Catalá" sería muy bien-venido" $"$.

Nunca llegó a producirse el regreso a España; ni a Granada, como deseaban sus amigos, ni a Córdoba, como los hermanos Falla tenían más o menos decidido en caso de se hubieran planteado su posibilidad de retorno. Aunque sí a Cádiz, pero ya sin vida. Una angina de pecho puso fin a la vida de Manuel de Falla el 14 de noviembre de 1946, cuando le faltaban nueve días para cumplir los setenta años.

E1 19 de noviembre se celebraron los funerales en la catedral de Córdoba y su cuerpo fue depositado provisionalmente en la cripta de los carmelitas en el cementerio de San Jerónimo de aquella localidad argentina. Entre sus amigos asistentes en aquellos momentos de despedida, se hallaban José Manuel Hernández Suárez, Juan José Castro y el profesor Pedro Ara, que embalsamó el cadáver y fue encargado personalmente por el embajador español de asistir a María del Carmen Falla y disponer lo necesario para la vuelta de los restos de don Manuel a su lugar de nacimiento ${ }^{111}$. Algunos de los amigos argentinos y exiliados españoles intentaron oponerse al regreso de los restos mortales de Falla a España argumentado que tal regreso era contrario a su voluntad"11. Si así ocurría, "El alma del maestro poseedora de su voluntad queda en la Argentina a la espera de la España que anheló"113. La decisión de su hermana Carmen fue definitiva, aunque dejando clara su intención de que no se politizara el acto $^{114}$ y finalmente el cadáver embalsamado de Manuel de Falla fue embarcado en el "Cabo de Buena Esperanza" hasta las islas Canarias y en un buque de la armada española, "El Cañonero", desde allí hasta Cádiz, donde el 9 de enero de 1947 fue depositado en la cripta de la catedral, cerca de la casa que le vio nacer. El suntuoso funeral, encabezado por el ministro de Justicia, Raimundo Fernández Cuesta, fue muy distinto al que él hubiera deseado pero, finalmente, el Gobierno conseguía estar al lado del compositor protagonizando pomposamente la ceremonia, aunque él ya nada pudiera hacer por evitarlo.

${ }^{110}$ Se encuentra entre la documentación legada por Hernández Suárez al Archivo Manuel de Falla. Carpeta 7.106, "Estado de don Manuel de Falla", sin fecha. En el mismo figura una anotación a lápiz que dice "no enviado".

111 AMF, carpeta 7.105. Nota manuscrita, sin firma, con membrete del Hotel Alhambra Palace de Granada.

112 REIN, Raanen: "Música, exilio y memoria. La lucha por los restos de Manuel de Falla", en Journal of Iberian and Latin American Studies, n. 2 (1996) pp. 22-39.

${ }^{113}$ DE PERSIA, J.: Los últimos años..., p. 250.

${ }^{114}$ En este sentido, María del Carmen Falla escribe desde Argentina a su hermano Germán, en España: "Respecto al cuerpo de Manolo hay que evitar por cuantos medios puedas todo homenaje político, que siempre le había horrorizado y le parecía algo así como de 'funerales cívicos'. Yo, recordando lo que él me decía, lo prohibí aquí. Querían llevarlo al teatro, pero yo me impuse y me obedecieron. Les dije que el cuerpo de mi hermano únicamente se llevaría a sitio sagrado, así que del hospital se llevó a la catedral, donde fue el funeral, y de allí al panteón de los carmelitas, porque él era hermano del Carmen”. DE PERSIA, J.: Los últimos años..., p. 247. 